Research papers

\title{
Stable isotope ratios reveal food source of benthic fish and crustaceans along a gradient of trophic status in the East China Sea
}

\author{
Ni-Na Chang a , Jen-Chieh Shiao ${ }^{\text {a,* }}$, Gwo-Ching Gong ${ }^{\mathrm{b}, \mathrm{c}}$, Shuh-Ji Kao ${ }^{\mathrm{d}}$, Chih-hao Hsieh ${ }^{\mathrm{a}}$ \\ a Institute of Oceanography, National Taiwan University, No. 1, Sec. 4, Roosevelt Road, Taipei, 10617 Taiwan, ROC \\ ${ }^{\mathrm{b}}$ Institute of Marine Environmental Chemistry and Ecology and Center of Excellence for Marine Bioenvironment and Biotechnology, National Taiwan Ocean \\ University, \\ 2 Pei-Ning Rd., Keelung, Taiwan, ROC \\ c Taiwan Ocean Research Institute (TORI), 219, Sec. 1, Dongfang Rd., Qieding Dist., Kaohsiung, Taiwan, ROC \\ ${ }^{\mathrm{d}}$ Research Center for Environmental Changes, Academia Sinica, 128, Sec. 2, Academia Rd., Nankang, Taipei, Taiwan, ROC
}

\section{A R T I C L E I N F O}

\section{Article history:}

Received 27 November 2013

Received in revised form

25 April 2014

Accepted 27 April 2014

Available online 16 May 2014

Keywords:

Nutrient

Particulate organic matter

Benthic ecosystem

Stable isotope

Trophic status

\begin{abstract}
A B S T R A C T
The East China Sea (ECS) receives large quantities of particulate organic matter (POM) and inorganic nutrients transported from the Changjiang (Yangtze River), which have produced high productivity in the northwestern ECS. This study evaluated potential contributions of terrigenous POM (allochthonous food source) and nutrient-induced marine production (autochthonous source) to the ECS benthic ecosystem by analyzing stable isotopic compositions of phytoplankton, zooplankton, benthic crustaceans and fish. Benthic consumers exhibited $\delta^{13} \mathrm{C}$ values similar to those of their autochthonous food sources (i.e., phytoplankton and zooplankton), revealing their major reliance on marine production. In contrast, the $\delta^{13} \mathrm{C}$ values of benthic fish $(-19.6 \%$ o to $-13.5 \%$ ) and crustaceans ( $-18.9 \%$ o to $-15.0 \%$ ) were much higher than that of terrigenous POM $(-25.7 \%$ ), which generally accounted for less than $20 \%$ of the most fish diet. Phytoplankton and zooplankton generally exhibited higher $\delta^{13} \mathrm{C}$ values at eutrophic and highly productive inshore sites than at oligotrophic offshore sites. This enrichment of inshore $\delta^{13} \mathrm{C}$ values was mainly attributed to lower photosynthetic fractionation during algal blooms, an effect that was further enhanced during flood period of the Changjiang. The $\delta^{13} \mathrm{C}$ values of demersal fish assemblages were also significantly higher at inshore sites and decreased seaward. However, fish $\delta^{15} \mathrm{~N}$ values and their estimated trophic levels showed relatively small spatial variation. The disproportionate variations in $\delta^{13} \mathrm{C}$ and $\delta^{15} \mathrm{~N}$ values suggested that the enriched $\mathrm{C}$ isotopic signatures derived from an elevated $\delta^{13} \mathrm{C}$ baseline of the inshore food web instead of trophic enrichment of the isotopic ratios. The significantly positive correlations between concentrations of chlorophyll $a$ and nutrients versus fish $\delta^{13} \mathrm{C}$ provided further evidence for the use of pelagic algal bloom materials by inshore consumers. The isotopic and oceanographic survey data suggested that inorganic nutrients discharged from the Changjiang River nourish benthic consumers in the ECS and play an important role in linking marine benthic ecosystems to local pelagic primary production as well as to the adjacent terrestrial watershed.
\end{abstract}

(c) 2014 Elsevier Ltd. All rights reserved.

\section{Introduction}

Coastal ecosystems adjacent to large rivers are tightly connected to terrestrial environments via large inputs of freshwater and materials. River inputs of nutrients greatly accelerate the growth of marine primary producers and nitrogen loadings are positively related to fisheries yields (Nixon et al., 1986). Understanding how marine communities utilize river-discharged materials is important for tracing energy flow and resources distribution from terrestrial to marine ecosystems (Antonio et al., 2010). During past decades,

\footnotetext{
*Corresponding author. Tel.: +8862 33663227; fax: +886233663744.

E-mail address: jcshiao@ntu.edu.tw (J.-C. Shiao).
}

anthropogenic activities have caused catastrophic changes in large rivers and the adjacent marginal seas, principally by overenrichment of nutrients (Nixon, 1995; Diaz, 2001). The global nitrogen and phosphorus fluxes from rivers to coastal oceans have grown more than two- to threefold over the past half century, resulting in more than 760 coastal areas undergoing eutrophication (Howarth et al., 1995; Galloway et al., 2004; Diaz et al., 2011). Nutrient-promoted phytoplankton blooms may positively nourish the local biota by providing organic matter (Graf, 1992; Nascimento et al., 2008), yet these blooms also may harm marine ecosystems by causing hypoxic conditions (Breitburg, 2002; Grall and Chauvaud, 2002). Though eutrophication generally originates in pelagic ecosystems, the effects of increased organic deposition, accelerated oxygen consumption, and modified habitat structure can transcend 
ecosystem boundaries (Grall and Chauvaud, 2002; Vadeboncoeur et al., 2003). Therefore, both the marine pelagic and benthic communities in the sea areas abutting rivers are susceptible to the effects of terrigenous nutrients.

The East China Sea (ECS) has experienced severe eutrophication since the 1960s due to the dramatic increase of nutrient fluxes from the third longest river in the world - the Changjiang (Yangtze River). Concentrations of dissolved inorganic nitrogen (DIN) and phosphate in the Changjiang water have risen more than five-fold between the 1960s and the end of 1990 (Wang, 2006). In the late 1990s more than $1.4 \times 10^{6} \mathrm{t} \mathrm{yr}^{-1}$ of inorganic nitrogen was conveyed from the Changjiang into the ECS (Gao and Wang, 2008). The nutrient overload increased the occurrence of spring algal blooms in the Changjiang estuary and ECS from less than 10 times per year to more than 80 times per year between the 1930s and 2000s (Zhou et al., 2008). Though the frequent algal blooms were thought to be deleterious by causing bottom-water hypoxia (Chen et al., 2007) and by damaging benthic communities (Chang et al., 2012), these bloom materials also could act as nutritious food for marine secondary producers and contribute to higher trophic consumers in the ECS ecosystem, particularly in the Changjiang freshwater impacted area (isohaline of salinity 31) where the highest algal biomass was observed (Gong et al., 2011).

Riverborne organic materials also have the potential to nourish benthic consumers. Terrestrial particulate organic matter (POM) could be incorporated by marine benthic food webs and contribute to fishery catches via ingestion by local macrofauna, such as molluscs, crustaceans and polychaetes (Gearing et al., 1991; Riera and Richard, 1996; Bouillon et al., 2000; Darnaude et al., 2004). The Changjiang annually transports about $4.4 \times 10^{6} \mathrm{t}$ of particulate organic carbon to the adjacent ECS (Dagg et al., 2004; Gao and Wang, 2008). The transported terrigenous particles could travel more than $250 \mathrm{~km}$ from shore (Wu et al., 2007a), thus potentially providing an alternative food source for the benthic consumers across the continental shelf. It remains unclear whether the ECS benthic consumers would concurrently utilize the autochthonous (marine primary production) and allochthonous organic matter (riverborne POM), and which the main food source is.

Stable carbon and nitrogen isotope analyses have been successfully applied to clarify trophic structure with multiple food sources (Minagawa and Wada, 1984; Peterson et al., 1985). The $\delta^{13} \mathrm{C}$ signal of terrestrial POM is generally isotopically lighter by $5-6 \%$ o than marine production and the $\delta^{13} \mathrm{C}$ undergoes little change (approx. $1 \%$, Peterson et al., 1985) during transmission through trophic levels. Thus, carbon isotopic ratio is increasingly applied to explore linkages between riverine material and marine ecosystems (Voss and Struck, 1997). The $C$ isotope variability of consumers along the terrestrial-estuarine-marine gradient indicates a natural enrichment trend of $\delta^{13} \mathrm{C}$ values from estuarine to coastal areas in riverinfluenced ecosystems such as the observations in Thames Estuary and Louisiana coastal waters (Leakey et al., 2008; Fry, 2011). This enrichment ranged from about 3\%o for POM (Fry and Wainright, 1911) to more than $7 \%$ o for benthic fish (Leakey et al., 2008) depending on the geographical scales of sampling, levels of fluvial influence, or trophic status of the environment. This increasing trend indicates both the mixing of terrestrial and marine organics and the significant differences in the baseline isotopic signatures along this spatial gradient because the carbon isotopic composition of primary producers would be modified in different nutrient regimes (Gearing et al., 1991; Savoye et al., 2003). In highly eutrophic and productive systems, the photosynthetic fractionation between DIC and organic C is often reduced, thus elevating the $\delta^{13} \mathrm{C}$ values of primary producers (Cifuentes et al., 1988). Stable nitrogen isotopes could assess organisms' trophic positions because consumers tend to have higher $\delta^{15} \mathrm{~N}$ than their foods by an average of 3-4\%o (Minagawa and Wada,
1984; Post, 2002). The dual isotope approach is thought to be reliable for investigating trophic structure (Post, 2002). Therefore, by analyzing the carbon and nitrogen isotopic compositions of food sources and consumers, the spatial and temporal variations in food utilization by benthic consumers across the ECS shelf may be clarified.

Spatial differences in benthic communities' diets are greatly determined by the shift in relative availabilities of food sources (Antonio et al., 2010, 2012). In the ECS, amounts of both algal bloom materials and riverborne POM are most concentrated in the Changjiang mouth and inshore waters and rapidly decrease seaward (Wu et al., 2003, 2007a; Gong et al., 2011). Therefore, we hypothesized that the benthic consumers may exhibit a spatial dietary shift from mixed food sources of terrestrial POM and marine production in the inner shelf to mono-source of in situ marine production in the outer shelf. By analyzing the isotopic compositions of demersal fish and crustaceans across the ECS continental shelf, we may ascertain how food utilization by benthic consumers varies along a trophic gradient. Moreover, determining the spatial variability in energy uptake by benthic consumers across an extensive shelf with land-based influence may allow further prediction about the effects of environmental changes on the benthic ecosystems.

\section{Materials and methods}

\subsection{Study sites and sample collection}

The demersal fish and benthic crustaceans were repeatedly collected from the ECS in July of 2008, 2009 and 2010. The details of sampling methods have been described in Chang et al. (2012). The surveyed sites encompassed large spatial scale and trophic gradients from the eutrophic inshore area to the mesotrophic and oligotrophic outer shelf (Fig. 1). The inshore sites (i.e. $<150 \mathrm{~km}$ from the land, sites $01, \mathrm{~A} 1, \mathrm{~B} 1, \mathrm{C} 1$ ) were generally shallower than $60 \mathrm{~m}$ and influenced by Changjiang freshwater discharge (Table 1). The trawled fish and benthos were frozen on board immediately and identified to species in the laboratory. Stable isotopic composition of several fish and crustacea species were determined. For the benthic crustaceans (decapoda and Stomatopoda), only the individuals collected from sites A1-A3 in July 2008 were analyzed.

In order to distinguish marine production from terrestrial POM, isotopic compositions of phytoplankton communities from both inshore and offshore sites in July 2009 and 2010 were analyzed (Fig. 1). Surface water samples from each station were first filtered

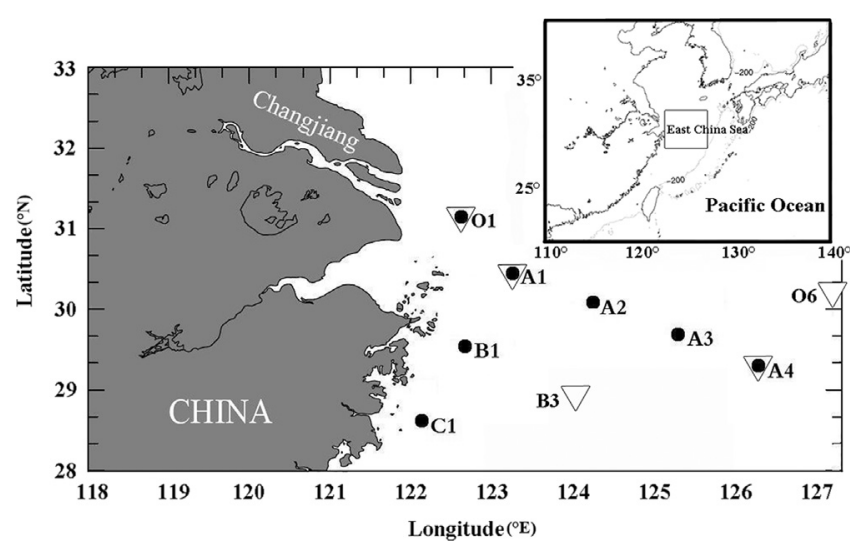

Fig. 1. Sampling sites for benthic consumers $(\bullet)$, phytoplankton and zooplankton $(\nabla)$ in the East China Sea. 
Table 1

Distance from shore, bottom depth, temperature, salinity, dissolved inorganic nitrogen (DIN), and chlorophyll $a(\mathrm{Chl})$ concentrations measured in the surface water $(2-3 \mathrm{~m})$ of the East China Sea, by year and site (Stn).

\begin{tabular}{|c|c|c|c|c|c|c|c|}
\hline $\begin{array}{l}\text { Time/ } \\
\text { location }\end{array}$ & Stn & $\begin{array}{l}\text { Distance } \\
(\mathrm{km})\end{array}$ & $\begin{array}{l}\text { Depth } \\
(\mathrm{m})\end{array}$ & $\begin{array}{l}\text { Temp. } \\
\left({ }^{\circ} \mathrm{C}\right)\end{array}$ & Salinity & $\begin{array}{l}\text { DIN } \\
(\mu \mathrm{M})\end{array}$ & $\begin{array}{l}\text { Chl } \\
\left(\mathrm{mg} \mathrm{m}^{-3}\right)\end{array}$ \\
\hline \multicolumn{8}{|l|}{ July 2008} \\
\hline Inshore & 01 & 96 & 46 & 22.76 & 21.62 & 32.67 & 3.27 \\
\hline Offshore & 06 & 529 & 102 & 28.68 & 32.29 & 2.19 & 0.15 \\
\hline Inshore & $\mathrm{A} 1$ & 139 & 60 & 25.10 & 28.52 & 23.42 & 3.33 \\
\hline Offshore & A2 & 273 & 60 & 27.41 & 33.28 & 1.57 & 0.13 \\
\hline Offshore & A3 & 377 & 90 & 27.02 & 31.90 & 2.22 & 0.58 \\
\hline Offshore & $\mathrm{A} 4$ & 465 & 102 & 28.81 & 32.63 & 1.44 & 0.14 \\
\hline Inshore & B1 & 64 & 45 & 24.26 & 28.31 & 35.78 & 2.28 \\
\hline \multicolumn{8}{|l|}{ July 2009} \\
\hline Inshore & 01 & 79 & 31 & 24.43 & 23.80 & 3.49 & 2.47 \\
\hline Inshore & $\mathrm{A} 1$ & 139 & 59 & 24.76 & 32.10 & 4.17 & 1.82 \\
\hline Offshore & $\mathrm{A} 2$ & 273 & 60 & 27.09 & 32.44 & 0.35 & 0.92 \\
\hline Offshore & A3 & 377 & 89 & 27.09 & 32.47 & 0.31 & 0.43 \\
\hline Offshore & $\mathrm{A} 4$ & 465 & 100 & 26.57 & 33.19 & 0.40 & 0.17 \\
\hline Offshore & B3 & 238 & 69 & 27.45 & 33.47 & 0.33 & 0.22 \\
\hline Inshore & $\mathrm{C} 1$ & 48 & 29 & 23.74 & 33.53 & 8.38 & 2.30 \\
\hline \multicolumn{8}{|l|}{ July 2010} \\
\hline Inshore & 01 & 77 & 26 & 24.43 & 19.33 & 40.28 & 1.99 \\
\hline Inshore & $\mathrm{A} 1$ & 139 & 60 & 24.52 & 25.44 & 22.05 & 3.36 \\
\hline Offshore & A2 & 273 & 59 & 26.23 & 29.50 & 6.64 & 2.55 \\
\hline Offshore & A3 & 377 & 90 & 26.04 & 29.41 & 3.44 & 1.41 \\
\hline Offshore & B3 & 238 & 70 & 26.36 & 30.09 & 6.10 & 1.20 \\
\hline Inshore & $\mathrm{C} 1$ & 48 & 32 & 25.34 & 24.80 & 27.10 & 4.67 \\
\hline
\end{tabular}

through a $50 \mu \mathrm{m}$ mesh size net to remove zooplankton. Then, $5 \mathrm{~L}$ of each water sample was filtered onto a pre-combusted $\left(500{ }^{\circ} \mathrm{C}, 24 \mathrm{~h}\right)$ $\mathrm{GF} / \mathrm{F}$ filter. After filtration the $\mathrm{GF} / \mathrm{F}$ filters were frozen at $-20{ }^{\circ} \mathrm{C}$ immediately for further isotopic analyses. At a given site, the isotopic composition of one filter sample was taken to represent the in situ marine primary production. Zooplankton assemblages were also collected by obliquely towing a $200 \mu \mathrm{m}$ mesh net from $10 \mathrm{~m}$ above the bottom to the surface water. At each sampling site, the collected zooplankton were further wet-sieved through serial meshes (mesh size $=2000,1000,500,363$ and $200 \mu \mathrm{m}$ ) to obtain size-fractioned samples (i.e., the composites of organisms belonging to the same size category). Stable isotopic analyses were performed for zooplankton samples of each size fraction and the $200-363 \mu \mathrm{m}$ size group was used to represent the pelagic primary consumers.

Hydrological data, including temperature and salinity, were measured in situ with a SeaBird Conductivity-Temperature-Depth recorder (SBE 9/11 plus, SeaBird Inc., USA). Water samples for chlorophyll $a$ and nutrients measurements were taken from the sea surface to near the bottom at intervals of $5-20 \mathrm{~m}$ by the CTD rosette assembly (Model1015, General Oceanics Inc., USA). Generally, six water samples at different depths would be collected and measured for each site and the sea surface measurements (generally 2-3 m depth) were used to study the relationships between environmental characteristics and isotopic values. For chlorophyll $a$ analysis, water samples from the sea surface were filtered through a GF/F filter paper (Whatman, $47 \mathrm{~mm}$ ) and determined fluorometrically with a precision of $0.02 \mathrm{mg} \mathrm{m}^{-3}$. Phosphate and silicate were measured by molybdenum blue and the silicomolybdenum blue methods (Pai et al., 1990) to precisions of $0.01 \mu \mathrm{M}$ and $0.5 \mu \mathrm{M}$, respectively. At each sampling site, concentrations of inorganic nitrogen were also determined for each of the six sampling depths using the analytic methods described in Parsons et al. (1984), Welschmeyer (1994) and Gong et al. (2000). Nitrate $\left(\mathrm{NO}_{3}^{-}\right)$, nitrite $\left(\mathrm{NO}_{2}^{-}\right)$and ammonium $\left(\mathrm{NH}_{4}^{+}\right)$were all determined independently and then pooled as dissolved inorganic nitrogen (DIN) for statistical computation. The analytical precision for salinity, nitrate, nitrite, and ammonium were $\pm 0.003 \mathrm{psu}$, $0.3 \mu \mathrm{M}, 0.01 \mu \mathrm{M}$, and $0.06 \mu \mathrm{M}$, respectively.

\subsection{Stable isotopic analysis}

A typical $\delta^{13} \mathrm{C}$ value for terrestrial organic matter is about -26.5\%o (Peters et al., 1978; Wada et al., 1987). However, the POM in the Changjiang freshwater has slightly higher $\delta^{13} \mathrm{C}$ values due to the influence of anthropogenic organic input (Wu et al., 2007a). The POM had similar $\delta^{13} \mathrm{C}$ values among upper and lower reaches as well as main stream and tributaries, with an average of $-25.6 \pm 0.7 \%$ o (Wu et al., 2007b). This study uses the isotopic ratios of POM in the Changjiang lower reach to represent the isotopic composition of riverborne POM, with $-25.7 \pm 0.1 \%$ ofor $\delta^{13} \mathrm{C}$ and $4.3 \% \pm \pm 1.0$ for $\delta^{15} \mathrm{~N}$ (Wu et al., 2007b).

Stable carbon and nitrogen isotopic ratios of the filtered phytoplankton, the whole body of zooplankton, and the muscle tissues of demersal fish and benthic crustaceans were determined. The phytoplankton and zooplankton samples (composites of several individuals) were acid-treated with $1 \mathrm{~N} \mathrm{HCl}$ to remove calcium carbonate $\left(\mathrm{CaCO}_{3}\right)$. The acidic treatment does not significantly change the isotopic values of organic matter (Kanaya et al., 2007). Muscle tissues from the upper dorsal trunk of fish and the cheliped of shrimp (mantis shrimp included) and crab were extracted from each individual. All the extracted tissue samples were dried at $60{ }^{\circ} \mathrm{C}$ for a minimum of $24 \mathrm{~h}$ and further ground into powder for isotopic analyses. The total contents of carbon and nitrogen as well as isotopic compositions of phytoplankton, zooplankton, and benthic consumers were determined using an automatic elemental analyzer (Carlo-Erba EA 2100) connected to a Thermo Finnigan Deltaplus Advantage isotope ratio mass spectrometry (IRMS). Analyzed results are expressed by the standard $\delta$ notation as the following:

$\delta X=\left(R_{\text {sample }} / R_{\text {standard }}-1\right) \times 1000(\%)$,

where $X$ is ${ }^{13} \mathrm{C}$ or ${ }^{15} \mathrm{~N}$, and $R$ is ${ }^{13} \mathrm{C} /{ }^{12} \mathrm{C}$ for carbon and ${ }^{15} \mathrm{~N} /{ }^{14} \mathrm{~N}$ for nitrogen. PeeDee belemnite (PDB) and atmospheric nitrogen were used as the $\delta^{13} \mathrm{C}$ and $\delta^{15} \mathrm{~N}$ standards, respectively. The U.S. Geological Survey standard \#40 (L-glutamic acid), which has certified $\delta^{13} \mathrm{C}$ value of $-26.2 \%$ and $\delta^{15} \mathrm{~N}$ value of $-4.5 \%$ and acetanilide (Merck) with $\delta^{13} \mathrm{C}$ value of $-29.8 \%$ and $\delta^{15} \mathrm{~N}$ value of $-1.5 \%$ o were used as working standards. The reproducibility of both carbon and nitrogen isotopic measurements was better than $0.15 \%$, which is much smaller than the wide distribution of isotopic compositions of the analyzed marine organisms in this study.

\subsection{Data analysis}

The trophic enrichment factors for $\delta^{15} \mathrm{~N}$ and $\delta^{13} \mathrm{C}$ values generally vary between 2.5-4.5\% (Minagawa and Wada, 1984; Post, 2002) and 1-2\%o (Wada et al., 1991), respectively, and the maximum and minimum trophic enrichment values were concurrently considered to demarcate ranges of terrestrial POM and marine production-based food webs on the carbon and nitrogen dual isotope plot. In July 2009 and 2010, the mean isotopic compositions of inshore (sites $01, \mathrm{~A} 1$ and $\mathrm{C} 1$ ) and offshore sites (sites A4 and B3) phytoplankton were calculated, respectively, and applied to represent the inshore and offshore marine primary production on the dual isotope plot. In July 2008, due to the lack of phytoplankton samples, the isotopic compositions of zooplankton at sites 01 and 06 were applied to represent the inshore and offshore marine production, respectively. A Bayesian isotopic mixing model was used to quantitatively estimate the contributions of terrestrial POM and marine production to fish diet with an open source SIAR package (Parnell et al., 2008). The SIAR model is fit via Markov Chain Monte Carlo (MCMC) methods and takes the variability in source and consumers' isotopic signatures, dietary 
isotopic fractionation, and elemental concentration into account. While computing the relative contributions, consumers inhabited inshore and offshore were separated due to the different baseline isotopic compositions. The SIAR model was setting to run 500,000 iterations and then produced a simulation of probability distributions of relative food source contributions to consumers' diet. We applied the mean value and residual errors of the estimated contributions to explore the major food source for the benthic fish.

To elucidate the temporal and spatial variabilities of isotopic signatures, the mean $\delta^{13} \mathrm{C}$ and $\delta^{15} \mathrm{~N}$ values of zooplankton and benthic consumers (fish and crustaceans) were compared among sampling sites and years by non-parametric ANOVA (KruskalWallis test) and multiple comparison (Tukey's HSD test). Trophic positions of demersal fish were calculated by the following equation:

$\mathrm{TP}_{\text {consumer }}=\lambda+\left(\delta^{15} \mathrm{~N}_{\text {consumer }}-\delta^{15} \mathrm{~N}_{\text {base }}\right) / \mathrm{TEF}$,

following Post (2002). $\lambda$ and $\delta^{15} \mathrm{~N}_{\text {base }}$ represented the trophic level and nitrogen isotopic ratios of marine primary consumers (i.e. zooplankton; $\lambda=2$ ). TEF is the trophic enrichment factor, which is generally about $3.2 \%$ or for actinopterygian fish (Sweeting et al., 2006). Simple linear regression was used to determine whether the isotopic values were associated with environmental characteristics, especially the eutrophic-related variables such as chlorophyll $a$ and DIN concentrations.

Table 2

Stable isotopic compositions $\left(\delta^{13} \mathrm{C}\right.$ and $\left.\delta^{15} \mathrm{~N}\right)$ and carbon to nitrogen ratios $(\mathrm{C} / \mathrm{N})$ of phytoplankton collected in July 2009 and 2010.

\begin{tabular}{lllll}
\hline Time & Stn & $\delta{ }^{13} \mathrm{C}\left(\%_{0}\right)$ & $\delta{ }^{15} \mathrm{~N}\left(\%_{0}\right)$ & $\mathrm{C} / \mathrm{N}$ \\
\hline \multirow{2}{*}{ July 2009 } & O1 & -20.9 & 1.7 & 6.3 \\
& A1 & -21.5 & 4.9 & 6.2 \\
& C1 & -20.3 & 3.9 & 5.5 \\
& A4 & -23.0 & 4.3 & 6.5 \\
July 2010 & B3 & -23.0 & 3.7 & 6.9 \\
& O1 & -21.1 & 2.3 & 4.5 \\
& A1 & -19.9 & 5.1 & 5.5 \\
& C1 & -21.3 & 2.7 & 5.9 \\
& B3 & -19.9 & 4.2 & 5.5 \\
\hline
\end{tabular}

\section{Results}

\subsection{Environmental characteristics across the ECS continental shelf}

The three-year summer sampling in the ECS continental shelf of environmental characteristics, i.e. salinity, temperature, inorganic nitrogen, and chlorophyll a concentrations showed pronounced gradient variations between inshore and offshore areas (Table 1). Concentrations of DIN decreased greatly from the inner shelf to the outer shelf and the concentrations at the inshore sites (01, A1, B1, and $\mathrm{C} 1$ ) were about tenfold higher than the offshore areas in July 2008 and 2010. The concentrations of chlorophyll $a$ in the inner shelf were generally higher than $2 \mathrm{mg} \mathrm{m}^{-3}$ and several samples even reached $3 \mathrm{mg} \mathrm{m}^{-3}$ (Table 1 ), which could be defined as a high nutrient pollution level in coastal marine surface waters (Swedish eutrophication classification system; Smith, 2003). Temporally, the monthly average discharge rates from the Changjiang were highest in July $2010\left(60,527 \mathrm{~m}^{3} \mathrm{~s}^{-1}\right)$ and lower in July 2008 and 2009 $\left(39,427\right.$ and $33,955 \mathrm{~m}^{3} \mathrm{~s}^{-1}$, respectively). Overall surface water salinity was lower and chlorophyll $a$ concentrations higher in July 2010 than in 2008 and 2009, due to the wide influence of the Changjiang flood during the summer of 2010 (Gong et al., 2011), in which the increase in chlorophyll $a$ concentration was not restricted to the inner shelf but also extended to the middle and outer shelf. In contrast, relatively lower concentrations of DIN and chlorophyll $a$ were observed in overall survey area in July 2009.

\subsection{Isotopic signatures of phytoplankton and zooplankton}

$\delta^{13} \mathrm{C}$ values of phytoplankton communities collected in July 2009 and 2010 varied from $-23.0 \%$ o to $-19.9 \%$ (Table 2). Phytoplankton in July 2009 exhibited slightly higher $\delta^{13} \mathrm{C}$ at inshore sites $01, \mathrm{~A} 1$ and $\mathrm{C} 1$ than offshore sites A4 and B3, yet 2010 samples showed smaller variability in $\delta^{13} \mathrm{C}$ values across the shelf. Phytoplankton $\delta^{15} \mathrm{~N}$ varied from $1.7 \%$ o to $5.1 \%$ and exhibited a larger isotopic range in the inner shelf $(1.7-5.1 \%$ ) than in outer shelf $(3.7-4.3 \%$ ).

The mean $\delta^{13} \mathrm{C}$ value of five size-fractioned zooplankton samples showed significantly higher values at inshore sites than offshore sites in July 2008 and 2009 (Table 3, $p=0.009$ and 0.0002, $\chi^{2}=6.82$ and 22.01, respectively; Kruskal-Wallis test). However, in July 2010, the inshore and offshore zooplankton exhibited similar mean $\delta^{13} \mathrm{C}$ values, without significant spatial difference $(p=0.12$, $\chi^{2}=5.81$; Kruskal-Wallis test). The $\delta^{13} \mathrm{C}$ values for zooplankton of the 200-363 $\mu \mathrm{m}$ size group were similar to the mean values of all size groups (Table 3 ), with more enriched $\delta^{13} \mathrm{C}$ values $(-21.3 \%$ o to

Table 3

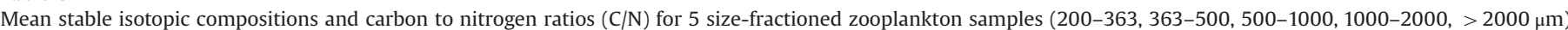

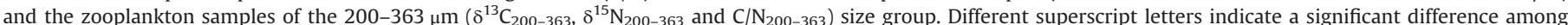
sampling sites in a given year (Kruskal-Wallis test and multiple comparisons).

\begin{tabular}{|c|c|c|c|c|c|c|c|c|c|c|}
\hline \multirow{2}{*}{ Time } & \multirow[t]{2}{*}{ Stn } & \multicolumn{4}{|l|}{$\delta^{13} \mathrm{C}(\% o)$} & \multicolumn{4}{|l|}{$\delta^{15} \mathrm{~N}(\% o)$} & \multirow[t]{2}{*}{$\mathrm{C} / \mathrm{N}_{200-363}$} \\
\hline & & Mean $( \pm S D)$ & $\chi^{2}$ & $p$-Value & $\delta^{13} C_{200-363}$ & Mean $( \pm S D)$ & $\chi^{2}$ & $p$-Value & $\delta^{15} \mathrm{~N}_{200-363}$ & \\
\hline July 2008 & $\begin{array}{l}01 \\
06\end{array}$ & $\begin{array}{l}-19.1 \pm 1.5^{\mathrm{a}} \\
-21.1 \pm 0.1^{\mathrm{b}}\end{array}$ & 6.82 & 0.009 & $\begin{array}{l}-19.2 \\
-21.4\end{array}$ & $\begin{array}{l}4.5 \pm 2.3 \\
6.4 \pm 1.2\end{array}$ & 3.15 & 0.075 & $\begin{array}{l}3.1 \\
5.6\end{array}$ & $\begin{array}{l}7.4 \\
6.9\end{array}$ \\
\hline July 2009 & $\begin{array}{l}\text { O1 } \\
\text { A1 } \\
\text { C1 } \\
\text { A4 } \\
\text { B3 }\end{array}$ & $\begin{array}{l}-20.5 \pm 0.8^{\mathrm{abc}} \\
-18.6 \pm 0.2^{\mathrm{c}} \\
-16.4 \pm 0.6^{\mathrm{ac}} \\
-22.0 \pm 0.2^{\mathrm{b}} \\
-20.9 \pm 0.4^{\mathrm{bc}}\end{array}$ & 22.01 & 0.0002 & $\begin{array}{l}-21.3 \\
-18.5 \\
-17.1 \\
-21.8 \\
-20.5\end{array}$ & $\begin{array}{l}3.8 \pm 2.7^{\mathrm{b}} \\
8.0 \pm 0.6^{\mathrm{a}} \\
8.3 \pm 1.1^{\mathrm{a}} \\
5.4 \pm 0.3^{\mathrm{ab}} \\
5.6 \pm 0.5^{\mathrm{ab}}\end{array}$ & 18.89 & 0.0008 & $\begin{array}{l}2.8 \\
7.3 \\
7.1 \\
5.3 \\
5.1\end{array}$ & $\begin{array}{l}8.4 \\
6.2 \\
6.4 \\
6.9 \\
7.1 \\
\end{array}$ \\
\hline July 2010 & $\begin{array}{l}\text { O1 } \\
\text { A1 } \\
\text { C1 } \\
\text { B3 }\end{array}$ & $\begin{array}{l}-19.9 \pm 1.2 \\
-19.3 \pm 0.8 \\
-20.5 \pm 0.7 \\
-19.3 \pm 0.7\end{array}$ & 5.81 & 0.121 & $\begin{array}{l}-21.1 \\
-20.0 \\
-19.5 \\
-20.1\end{array}$ & $\begin{array}{l}4.6 \pm 1.3^{\mathrm{ab}} \\
4.6 \pm 1.2^{\mathrm{ab}} \\
1.6 \pm 1.3^{\mathrm{b}} \\
7.4 \pm 0.6^{\mathrm{a}}\end{array}$ & 14.86 & 0.002 & $\begin{array}{l}3.8 \\
3.4 \\
1.2 \\
6.8\end{array}$ & $\begin{array}{l}5.9 \\
5.8 \\
5.3 \\
6.4\end{array}$ \\
\hline
\end{tabular}


$-17.1 \%$ ) in the inner shelf than in the outer shelf $(-21.8 \%$ o to $-20.1 \%$, Table 3$)$. In contrast, $\delta^{15} \mathrm{~N}$ values for the $200-363 \mu \mathrm{m}$ zooplankton size group exhibited generally lower values and larger variation at inshore sites $(1.2-7.3 \%$ ) than at offshore sites (5.1-6.8\%o, Table 3).

\subsection{Isotopic signature of benthic crustacean}

The isotopic compositions of 51 individual benthic crustaceans belonging to 12 species of decapoda and stomatopoda were analyzed. The $\mathrm{C}$ and $\mathrm{N}$ dual isotope plot of all crustaceans showed a wide range of $\delta^{13} \mathrm{C}(-18.9 \%$ to $-15.0 \%$, Fig. 2) with significantly higher values at site $\mathrm{A} 1$ than that at sites A2 and A3 (Table 4, $p<0.0001, \chi^{2}=34.48$; Kruskal-Wallis test). Comparing isotopic values of the same species among sites, several crustacea species also had higher $\delta^{13} \mathrm{C}$ values at the inshore sites A1 (Fig. 3a) and the spatial isotopic difference between inshore and offshore sites reached $2.1 \%$ for Charybdis bimaculata. The $\delta^{15} \mathrm{~N}$ values of

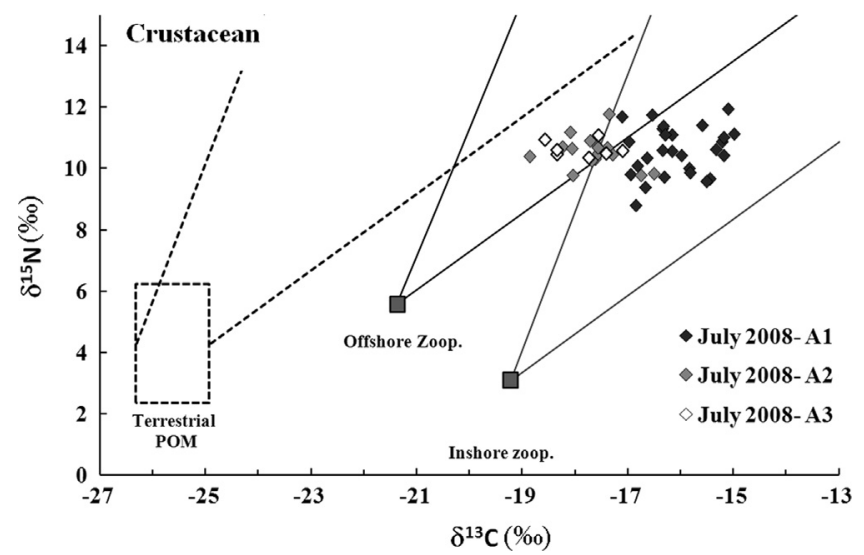

Fig. 2. Carbon and nitrogen dual isotope plot of crustaceans collected from the East China Sea in July 2008. Funnel-shaped areas show the potential isotopic ranges of consumers that fed on inshore and offshore marine primary consumers (herein zooplankton) and terrestrial particulate organic matters (POM), considering trophic enrichment of $+1 \%$ in $\delta^{13} \mathrm{C}$ and $+4.5 \%$ in $\delta^{15} \mathrm{~N}$ (lines of steeper slope with $\delta^{15} \mathrm{~N}$ : $\delta^{13} \mathrm{C}=4.5$ ) and of $+2 \%$ in $\delta^{13} \mathrm{C}$ and $+2.5 \%$ in $\delta^{15} \mathrm{~N}$ (lines of gradual slope with $\delta^{15} \mathrm{~N}: \delta^{13} \mathrm{C}=1.25$ ) crustaceans varied from $8.8 \%$ to $11.8 \%$ with no significant difference among sampling sites (Table $4, p=0.95, \chi^{2}=0.1$; Kruskal-Wallis test). The $\delta^{15} \mathrm{~N}$ values for crustacea species exhibited larger interspecific variation at inshore site A1 than offshore sites (Fig. 3b)
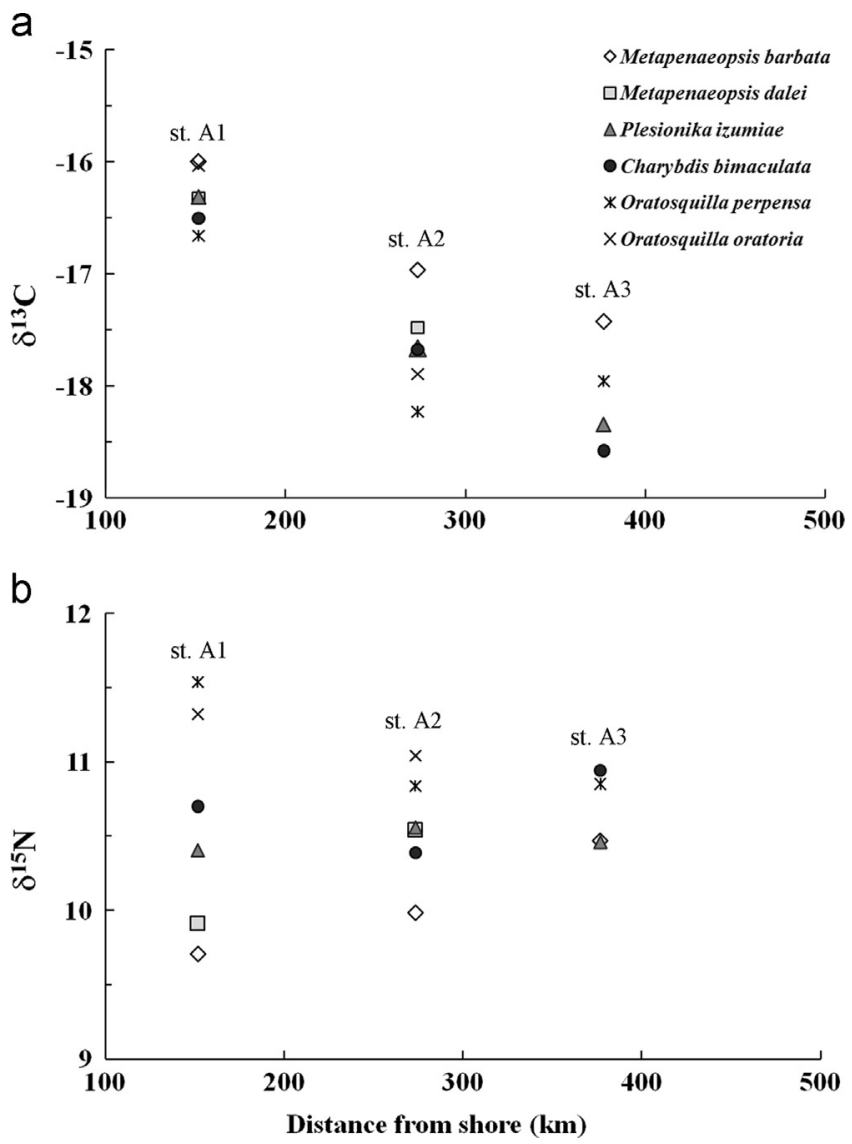

Fig. 3. (a) $\delta^{13} \mathrm{C}$ and (b) $\delta^{15} \mathrm{~N}$ values of crustacea species from the East China Sea versus the distance from shore. Each data point represented the mean isotopic value of one species.

Table 4

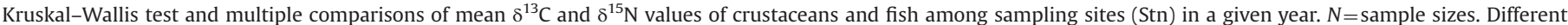
superscript letters indicate a significant difference among sites in a given year.

\begin{tabular}{|c|c|c|c|c|c|c|c|c|c|c|c|c|c|}
\hline \multirow{2}{*}{ Time } & \multirow[t]{2}{*}{ Stn } & \multirow[t]{2}{*}{$N$} & \multirow[t]{2}{*}{ species } & \multirow{2}{*}{$\begin{array}{l}\text { Total } \\
\text { df }\end{array}$} & \multicolumn{4}{|l|}{$\delta^{13} \mathrm{C}(\%)$} & \multicolumn{4}{|c|}{$\delta^{13} \mathbf{N}(\% o)$} & \multirow[t]{2}{*}{ Trophic leve } \\
\hline & & & & & Mean & $\mathrm{SD}$ & $\chi^{2}$ & $p$-Value & Mean & SD & $\chi^{2}$ & $p$-Value & \\
\hline \multicolumn{14}{|l|}{ Crustacean } \\
\hline \multirow[t]{3}{*}{ July 2008} & $\mathrm{~A} 1$ & 27 & 12 & \multirow[t]{3}{*}{50} & $-16.1^{\mathrm{a}}$ & 0.7 & \multirow[t]{3}{*}{34.48} & \multirow[t]{3}{*}{$<0.0001$} & 10.6 & 0.8 & \multirow[t]{3}{*}{0.1} & \multirow[t]{3}{*}{0.95} & - \\
\hline & A2 & 17 & 6 & & $-17.6^{\mathrm{b}}$ & 0.6 & & & 10.6 & 0.5 & & & - \\
\hline & A3 & 7 & 4 & & $-17.9^{\mathrm{b}}$ & 0.6 & & & 10.7 & 0.3 & & & - \\
\hline \multicolumn{14}{|l|}{ Fish } \\
\hline \multirow[t]{5}{*}{ July 2008} & B1 & 14 & 5 & \multirow[t]{5}{*}{164} & $-15.3^{\mathrm{a}}$ & 0.7 & \multirow[t]{5}{*}{99.71} & \multirow[t]{5}{*}{$<0.0001$} & $10.8^{\mathrm{b}}$ & 0.5 & \multirow[t]{5}{*}{26.23} & \multirow[t]{5}{*}{$<0.0001$} & - \\
\hline & $\mathrm{A} 1$ & 39 & 14 & & $-16.1^{\mathrm{a}}$ & 0.8 & & & $11.2^{\mathrm{ab}}$ & 0.9 & & & $4.1 \pm 0.3$ \\
\hline & A2 & 54 & 22 & & $-17.6^{\mathrm{b}}$ & 0.6 & & & $11.3^{\mathrm{b}}$ & 0.9 & & & - \\
\hline & A3 & 34 & 17 & & $-17.5^{\mathrm{b}}$ & 0.7 & & & $11.8^{\mathrm{a}}$ & 0.9 & & & - \\
\hline & A4 & 24 & 11 & & $-18.2^{c}$ & 0.5 & & & $10.7^{\mathrm{b}}$ & 0.9 & & & $3.6 \pm 0.3$ \\
\hline \multirow[t]{5}{*}{ July 2009} & $\mathrm{C} 1$ & 11 & 3 & \multirow[t]{5}{*}{77} & $-16.9^{a}$ & 0.7 & \multirow[t]{5}{*}{22.70} & \multirow[t]{5}{*}{0.0001} & $10.2^{\mathrm{b}}$ & 0.9 & \multirow[t]{5}{*}{26.8} & \multirow[t]{5}{*}{$<0.0001$} & $3.0 \pm 0.3$ \\
\hline & $\mathrm{A} 1$ & 25 & 8 & & $-17.2^{\mathrm{a}}$ & 0.6 & & & $10.7^{\mathrm{b}}$ & 0.8 & & & $2.8 \pm 0.2$ \\
\hline & $\mathrm{A} 2$ & 18 & 6 & & $-17.5^{\mathrm{ab}}$ & 0.6 & & & $11.4^{\mathrm{a}}$ & 0.8 & & & $3.4 \pm 0.3$ \\
\hline & A3 & 14 & 6 & & $-17.8^{\mathrm{b}}$ & 0.4 & & & $11.7^{\mathrm{a}}$ & 0.5 & & & $3.5 \pm 0.2$ \\
\hline & A4 & 10 & 4 & & $-17.8^{\mathrm{b}}$ & 0.4 & & & $11.2^{\mathrm{ab}}$ & 0.8 & & & $3.2 \pm 0.2$ \\
\hline \multirow[t]{5}{*}{ July 2010} & 01 & 9 & 3 & \multirow[t]{5}{*}{86} & $-15.9^{\mathrm{ac}}$ & 0.9 & \multirow[t]{5}{*}{54.22} & $<0.0001$ & $8.8^{\mathrm{d}}$ & 1.2 & 35.77 & $<0.0001$ & $3.0 \pm 0.4$ \\
\hline & $\mathrm{C} 1$ & 7 & 2 & & $-14.3^{\mathrm{a}}$ & 0.4 & & & $9.5^{\mathrm{cd}}$ & 0.8 & & & $3.1 \pm 0.2$ \\
\hline & $\mathrm{A} 1$ & 29 & 10 & & $-15.4^{\mathrm{a}}$ & 0.8 & & & $10.6^{\mathrm{bc}}$ & 0.6 & & & $2.7 \pm 0.2$ \\
\hline & $\mathrm{A} 2$ & 21 & 10 & & $-16.7^{\mathrm{bc}}$ & 0.7 & & & $11.2^{\mathrm{a}}$ & 0.6 & & & $3.2 \pm 0.2$ \\
\hline & A3 & 21 & 7 & & $-17.5^{\mathrm{b}}$ & 0.9 & & & $11.0^{\mathrm{ab}}$ & 0.6 & & & $3.1 \pm 0.2$ \\
\hline
\end{tabular}




\subsection{Isotopic signature and relative food source contributions for fish communities}

A total of 41 species of demersal fishes collected from 15 trawls in July 2008, 2009 and 2010 were analyzed for their stable isotopic compositions. Overall, the $\delta^{13} \mathrm{C}$ values of individual fish ranged from $-19.2 \%$ o to $-13.7 \%$ o (Supplementary Table 1 ). The isotopic composition of most fish was located within the range of marine production at both inshore and offshore sites, but relatively fewer fish showed evidence of incorporating terrestrial POM (Fig. 4). The carbon source for demersal fish mostly derived from marine origin (71.8-98.7\%) and terrestrial POM generally accounted for less than $10 \%$ of fish diet at most sites in July 2008 and 2010 estimated by Bayesian mixing model. The largest contributions by terrestrial POM occur in July 2009 with the contributions of terrestrial POM ranged between $3.4 \%$ and $25.3 \%$ (Table 5).
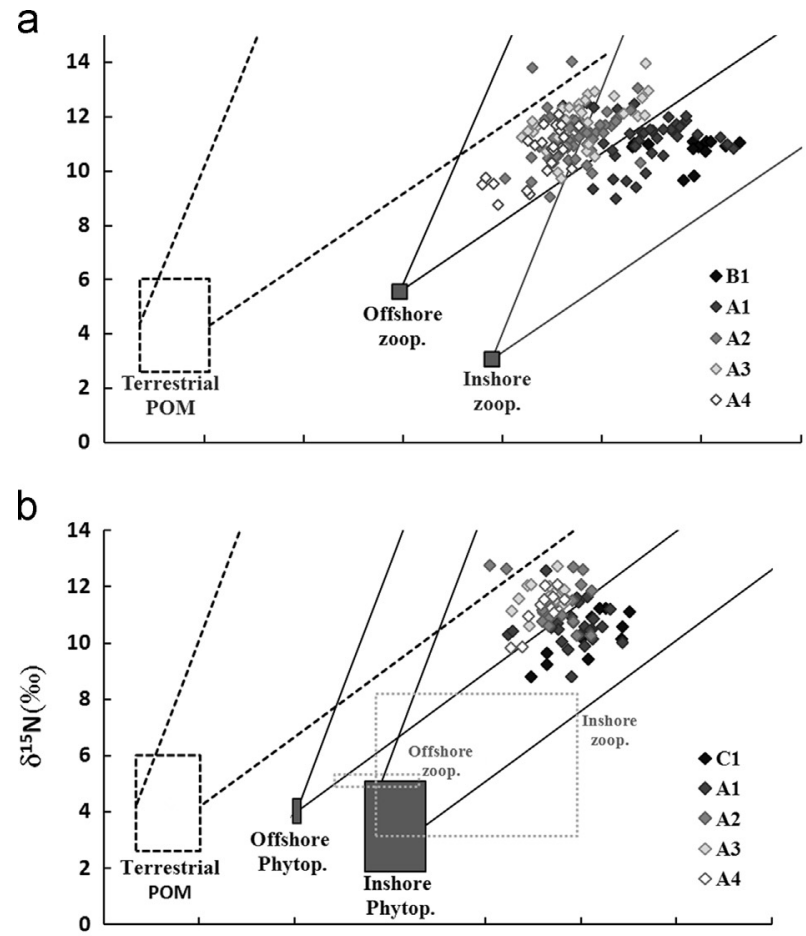

C

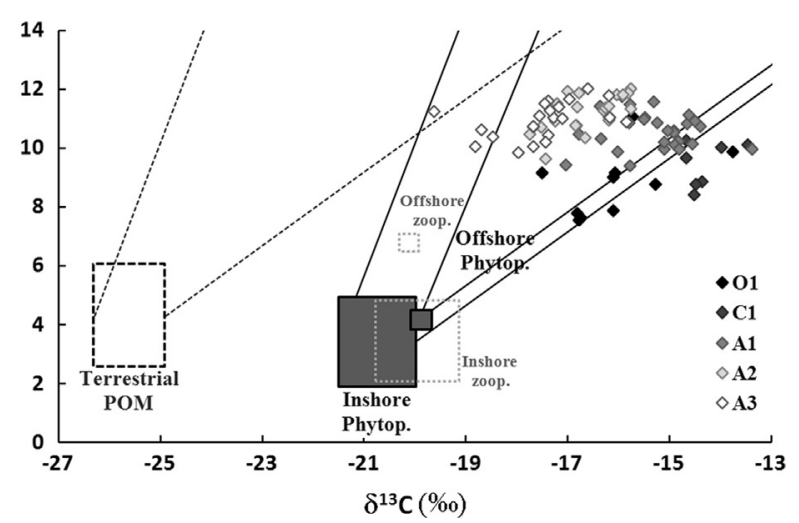

Fig. 4. Carbon and nitrogen dual isotope plot of demersal fish collected from the East China Sea in July of (a) 2008, (b) 2009 and (c) 2010. Funnel-shaped areas showing the potential isotopic composition ranges of consumers that fed on marine production, i.e. zooplankton (Zoop.) and phytoplankton (Phytop.) or terrestrial POM, considering trophic enrichment of $+1 \%$ in $\delta^{13} \mathrm{C}$ and $+4.5 \%$ in $\delta^{15} \mathrm{~N}$ (lines of steeper slope with $\delta^{15} \mathrm{~N}: \delta^{13} \mathrm{C}=4.5$ ) and of $+2 \%$ in $\delta^{13} \mathrm{C}$ and $+2.5 \%$ in $\delta^{15} \mathrm{~N}$ (lines of gradual slope with $\left.\delta^{15} \mathrm{~N}: \delta^{13} \mathrm{C}=1.25\right)$. Each data point indicates the isotopic composition of one individual.
Overall, the mean $\delta^{13} \mathrm{C}$ value of the fish assemblage at a given site varied from $-18.2 \%$ o to $-14.3 \%$. The differences of $\delta^{13} \mathrm{C}$ values between fish assemblages and terrestrial POM ranged from $7.4 \%$ o to $11.3 \%$ o with larger differences observed closer to the shore (over 10\% at inshore sites B1 in 2008, C1 and A1 in 2010, Fig. 5). For each sampling year, demersal fish at inshore sites exhibited significantly higher mean $\delta^{13} \mathrm{C}$ values than at offshore sites (Table 4). The highest $\delta^{13} \mathrm{C}$ values occurred at the inshore sites B1 (2008) and C1 (2009 and 2010). Fish collected in July 2008 and 2010 showed larger spatial variation and generally higher $\delta^{13} \mathrm{C}$ values (Fig. 5). In contrast, fish assemblages in July 2009 exhibited smaller isotopic variation and more negative $\delta^{13} \mathrm{C}$ values. Among years, fish communities from sites $\mathrm{A} 1$ and $\mathrm{A} 2$ exhibited significantly higher $\delta^{13} \mathrm{C}$ values in July 2010 than in other years $\left(\chi^{2}=44.15\right.$ and 21.09 for sites $\mathrm{A} 1$ and $\mathrm{A} 2$, respectively; $p<0.0001$ in both case).

The mean $\delta^{15} \mathrm{~N}$ values of fish assemblage ranged between $8.8 \%$ and $11.8 \%$ (Table 4 ). Mean $\delta^{15} \mathrm{~N}$ values of fish assemblages also differed significantly among sampling sites $\left(p<0.0001, \chi^{2}=26.23\right.$, 26.80, and 35.77 for 2008, 2009, and 2010; Kruskal-Wallis test) and exhibited an opposite trend to that of $\delta^{13} \mathrm{C}$ values. The fish assemblage inhabiting the inner shelf had slightly and significantly lower $\delta^{15} \mathrm{~N}$ values while higher values occurred in the middle to outer shelf. The mean trophic position of fish assemblages were calculated based on the isotopic compositions of primary consumers (i.e. zooplankton). The trophic positions of fish of all sampling sites generally ranged between 3 and $<5$ and most fishes exhibited the trophic level $>3$, characterizing then as carnivores (Supplementary Table 1).

\subsection{Spatiotemporal variations in $\delta^{13} \mathrm{C}$ and $\delta^{15} \mathrm{~N}$ of fish species}

The fish species Amblychaeturichthys hexanema, Antennarius striatus and Cynoglossus interruptus were found at most stations. The $\delta^{13} \mathrm{C}$ values of these species showed the highest values in July 2010 and in the inshore areas ( $<150 \mathrm{~km}$ from shore) and gradually decreased with distance from the shore (Fig. 6). The largest $\delta^{13} \mathrm{C}$ differences between inshore and offshore sites reached $2.9 \%$ for $A$. striatus collected in 2008. The seaward decreasing trend of $\delta^{13} \mathrm{C}$ values was less pronounced in July 2009. Conversely, the $\delta^{15} \mathrm{~N}$ of demersal fishes increased from inshore to offshore sites (Fig. 6). The largest spatial variation in $\delta^{15} \mathrm{~N}$ values was $1.8 \%$ observed in A. hexanema in 2010 .

Table 5

Relative contributions of marine (\% $\left.\mathrm{C}_{\text {phyto/zoop }}\right)$ and terrestrial $\left(\% \mathrm{C}_{\mathrm{tPOM}}\right)$ carbon sources for fish, by year and site (Stn).

\begin{tabular}{lccccc}
\hline \multirow{2}{*}{ Time } & Stn & $\mathrm{C}_{\text {phyto/zoop }}(\%)$ & Residual error & $\mathrm{C}_{\text {tPOM }}(\%)$ & Residual error \\
\hline \multirow{2}{*}{ July 2008 } & B1 & 95.3 & 5.00 & 4.7 & 1.83 \\
& A1 & 98.7 & 5.19 & 1.3 & 0.47 \\
& A2 & 98.3 & 2.73 & 1.7 & 2.57 \\
& A3 & 97.0 & 3.30 & 3.0 & 2.74 \\
& A4 & 97.0 & 2.22 & 3.0 & 1.99 \\
July 2009 & C1 & 89.6 & 3.69 & 10.4 & 2.68 \\
& A1 & 96.6 & 3.88 & 3.4 & 1.89 \\
& A2 & 84.4 & 4.62 & 15.6 & 4.06 \\
& A3 & 81.0 & 5.00 & 19.0 & 3.93 \\
& A4 & 74.7 & 4.63 & 25.3 & 4.20 \\
July 2010 & O1 & 86.2 & 3.94 & 13.8 & 3.05 \\
& C1 & 71.8 & 4.77 & 28.2 & 5.81 \\
& A1 & 96.0 & 5.32 & 4.0 & 2.90 \\
& A2 & 96.6 & 4.10 & 3.4 & 1.55 \\
& A3 & 96.1 & 3.84 & 3.9 & 1.10 \\
\hline
\end{tabular}



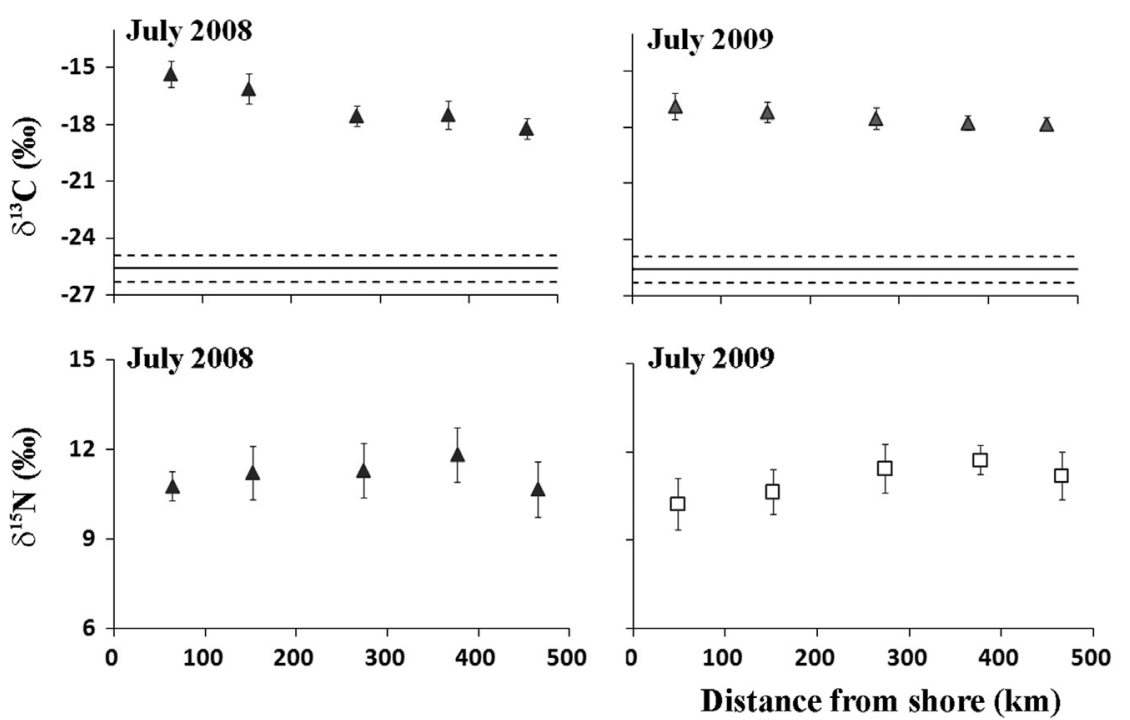

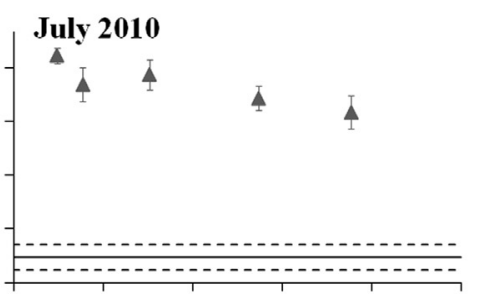

July 2010

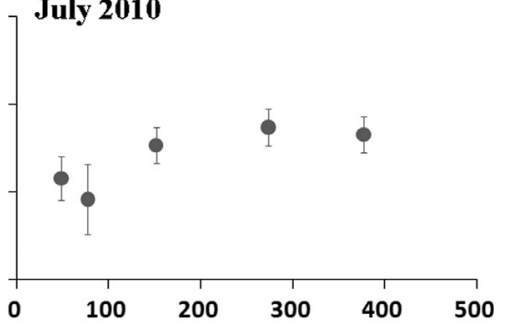

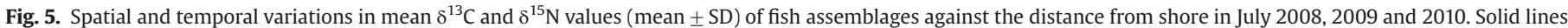
represented $\delta^{13} \mathrm{C}$ values of terrestrial POM $(-25.6 \%$ ) and dotted lines showed \pm 1 standard deviation.
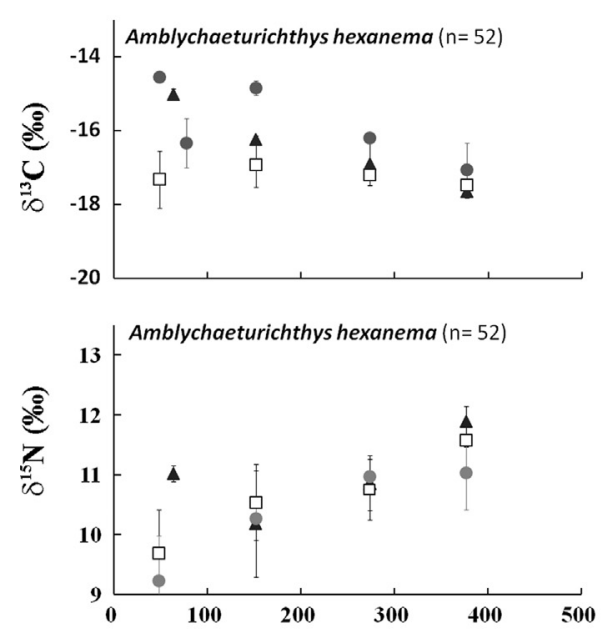
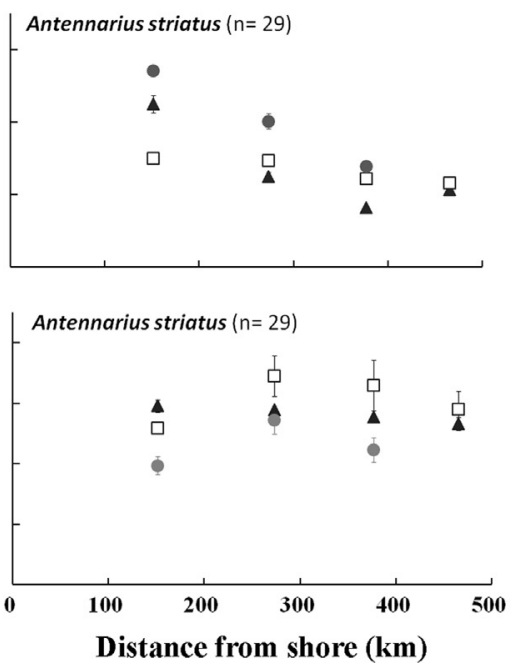
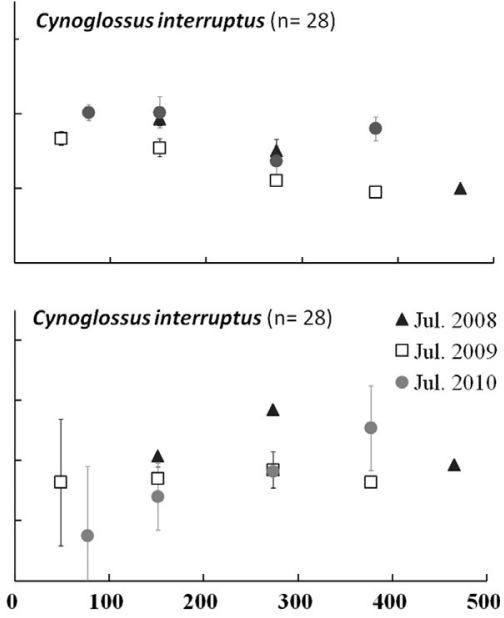

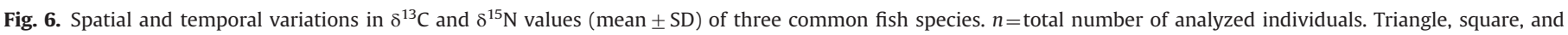
circle symbols represented the fish sampled in July 2008, 2009 and 2010, respectively.

\subsection{Relationships between environmental characters and isotopic composition}

Linear regressions of fish $\delta^{13} \mathrm{C}$ values against surface DIN, $\mathrm{PO}_{4}$, $\mathrm{SiO}_{3}$, and chlorophyll $a$ concentrations across the three sampling years showed significant positive slopes ( $p<0.0001$, Fig. 7). Highly eutrophic conditions and corresponding high values of $\delta^{13} \mathrm{C}$ mainly occurred in July 2008 and 2010. In contrast, fish $\delta^{15} \mathrm{~N}$ negatively correlated to $\mathrm{DIN}, \mathrm{SiO}_{3}$, and chlorophyll $a$ concentrations (Fig. 8). Those sites with higher concentrations of nutrients and chlorophyll $a$ generally had lower mean $\delta^{15} \mathrm{~N}$ values of fish assemblages.

\section{Discussion}

\subsection{Food source for the benthic ecosystem}

In the East China Sea, most fish exhibited higher dependence on in situ marine production, which is characterized by higher $\delta^{13} \mathrm{C}$ values than on terrestrial particulate organic matter (POM). The large differences in $\delta^{13} \mathrm{C}$ values between fish assemblages and terrestrial POM reflected less use of the Changjiang riverborne POM by local benthos. Although the microbial reworking on terrestrial POM may further modify $\delta^{13} \mathrm{C}$ values of the remaining organic matters along the transportation from river to shelf (Hedges et al., 1997; Wu et al., 2003), the $\delta^{13} \mathrm{C}$ values for sedimentary organic matter ( $-22.4 \%$ o to $-20.1 \%$ ) were still much lower than that for fish assemblages (Kao et al., 2003). The largest $\delta^{13} \mathrm{C}$ difference between sedimentary $\mathrm{OM}$ and fish even reached $8 \%$ in the inner shelf (Supplementary Table 2). These results implied strong diet selection of the benthic consumers and reflected residual terrestrial POM in the shelf sediments.

Although river inputs of terrestrial origin POM can potentially contribute to coastal fishery productivity, we found that fish receive slightly higher energetic benefits from terrestrial POM only under the condition of lower river discharge instead (e.g., July 2009). The exploitation of terrestrial POM by estuarine macroinvertebrates is regarded to be an important pathway for nourishing some marine benthic consumers (Riera and Richard, 1996; 

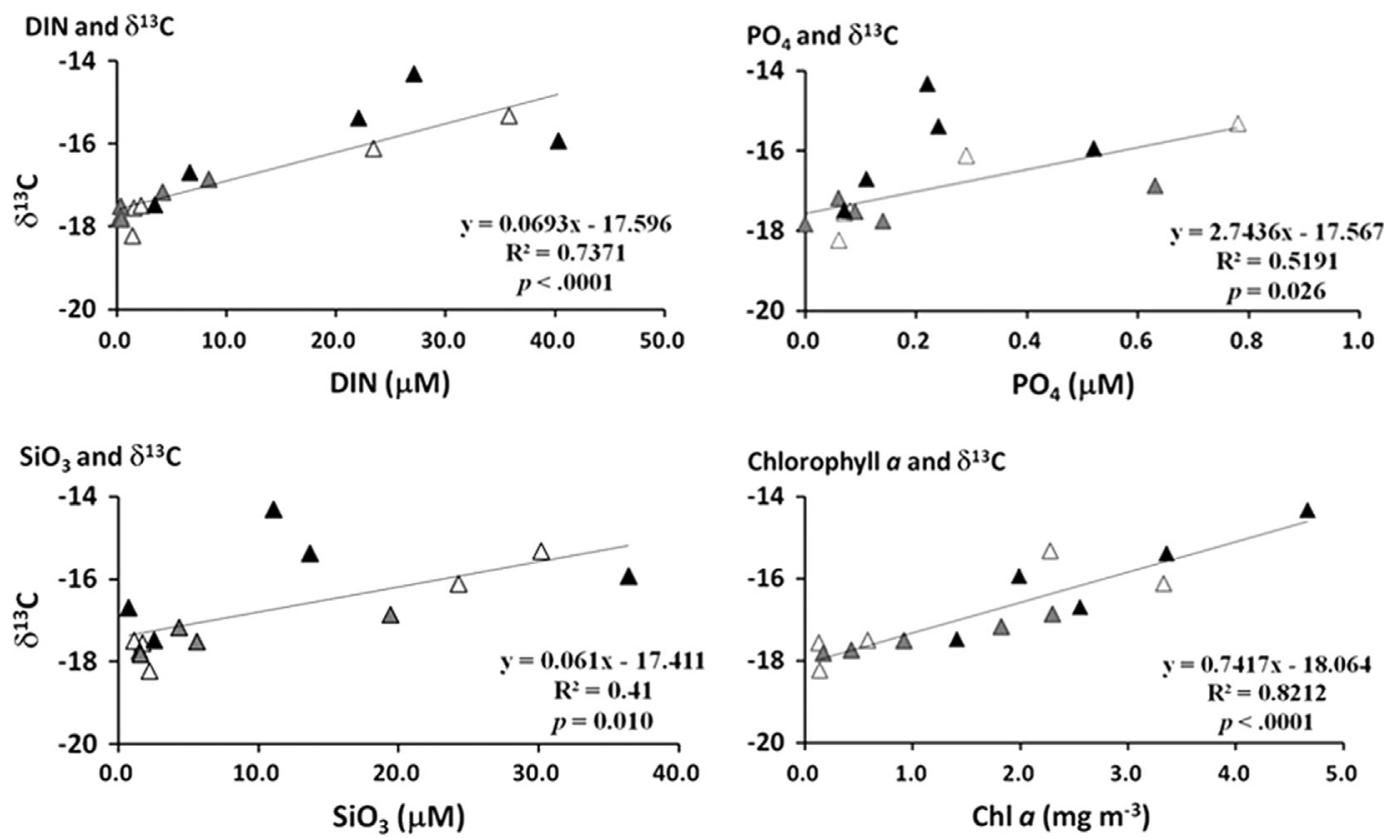

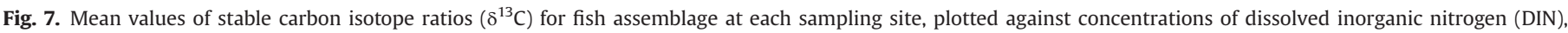

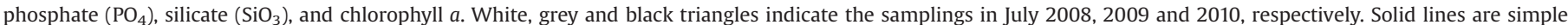
linear regressions.
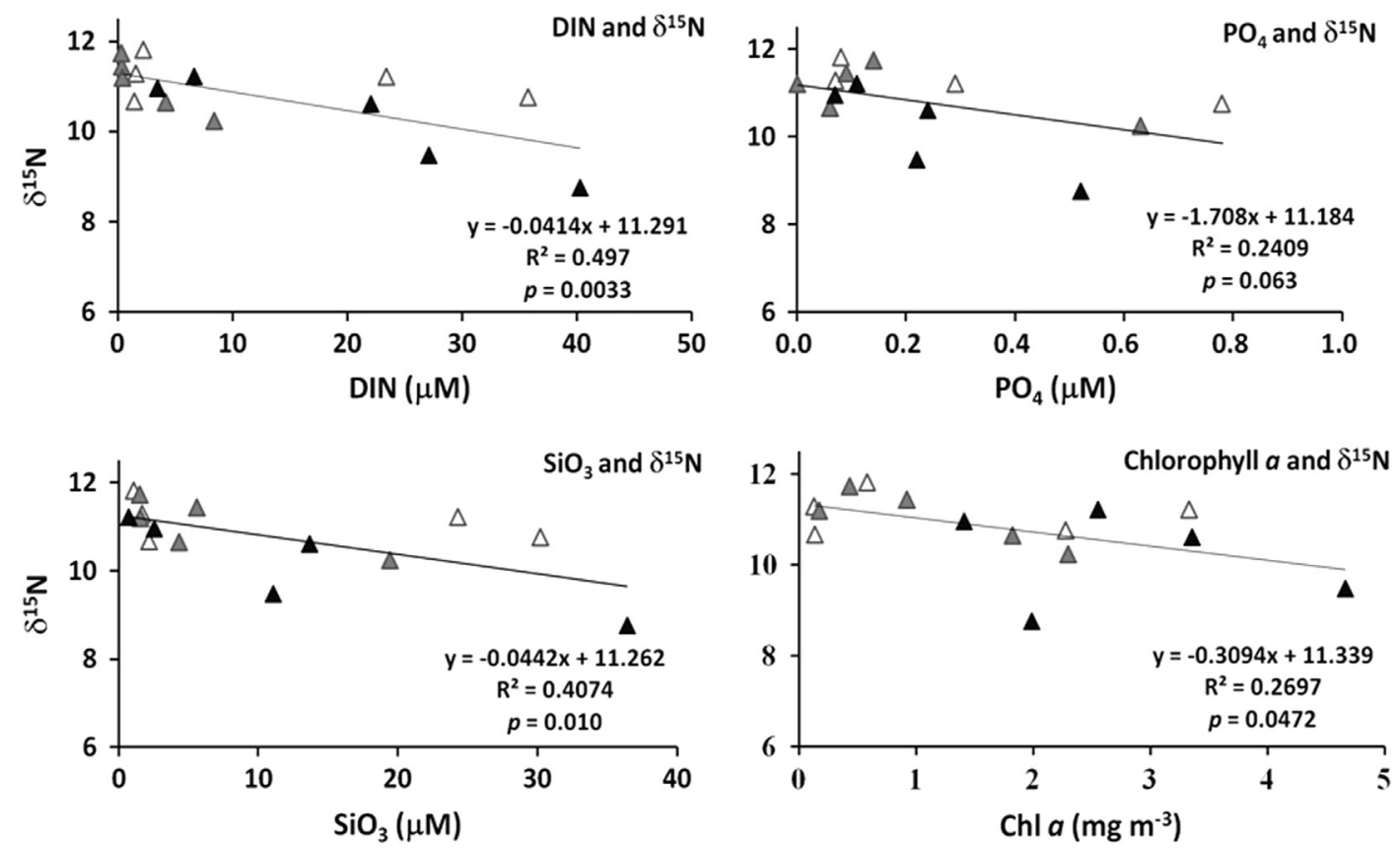

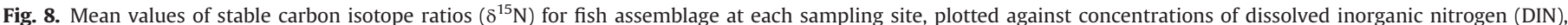

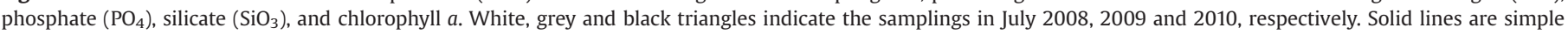
linear regressions.

Bouillon et al., 2000; Darnaude et al., 2004). For instance, the sole (Solea solea) fishery yield in the Gulf of Lion (NW Mediterranean) was closely related to the density of deposit-feeding polychaetes, which mainly fed on the terrigenous POM derived from the Rhone River (Darnaude et al., 2004). However, the terrestrial material is rich with cellulose and lignin that are refractory and poorly digested by most aquatic consumers, thus restricting its contribution to higher consumers in most estuaries and coastal areas (Deegan and Garritt, 1997; Cividanes et al., 2002). Moreover, the annual load of Changjiang discharged POC $\left(4.4 \times 10^{6} \mathrm{t} \mathrm{yr}^{-1}\right.$, Dagg et al., 2004) was only equaled about half of the organic carbon derived from DIN (ca $6.6 \times 1.4 \times 10^{6} \mathrm{t} \mathrm{yr}^{-1}=9.3 \times 10^{6} \mathrm{tyr}^{-1}$, Gao and Wang, 2008), based on the Redfield ratio of 106:16 for C:N, thus implying the higher availability and dominance by inorganic nutrients derived marine primary production in this system. In addition, consumers' uptake of terrestrial and marine phytodetritus is greatly determined by the availability of organic nitrogen content (Hunter et al., 2013) which acts as a limiting nutrient for organisms. 
Due to the typically poor $\mathrm{N}$ contents of terrestrial POM, most benthic fauna showed preferential incorporation of organic Nenriched marine production (Mann, 1988; Evrard et al., 2010). The $\mathrm{C}: \mathrm{N}$ ratios for the Changjiang riverborne POM ranged between 7.6 and 15.8 (Wu et al., 2007b), which were obviously higher (lower organic $\mathrm{N}$ contents) than the in situ phytoplankton ( $\mathrm{C}: \mathrm{N}$ ratios $=4.5$ to 6.9; Table 2). Therefore, though the terrestrial POM transported by the Changjiang was estimated to contribute about $50 \%$ of the total POM in the water column within a distance of $150 \mathrm{~km}$ from the river mouth (Wu et al., 2003), the benthic fish inhabiting this inshore area tended to mostly feed on marine production.

Conversely, marine production is a more nutritious energy source for estuarine and marine consumers (Antonio et al., 2012). Marine primary production can both closely correlate to the survival and growth rates of larval fish and energize benthic juvenile and adult fish through the food web. Primary production is generally high in the northwestern half of the ECS continental shelf where the annual primary production can reach $155 \mathrm{~g} \mathrm{C} \mathrm{m}^{-2}$ (Gong et al., 2003). Therefore, phytoplankton production in the ECS plays a more important role in sustaining the local benthic food web than does terrestrial POM when compared with other relatively oligotrophic seas such as the Gulf of Lions (NW Mediterranean Sea), where primary productivity tends to be limited by P-depletion (Diaz et al., 2001; Darnaud et al., 2004).

In addition to marine phytoplankton, studies in coastal areas reveal great contributions by benthic primary production to the benthic food web based on the enriched $\delta^{13} \mathrm{C}$ of benthos (e.g. Antonio et al., 2012). Nevertheless, the elevated $\delta^{13} \mathrm{C}$ values for the demersal fish and crustaceans at the inshore sites of the ECS were not likely caused by the ingestion of benthic primary production because the large sediment load from the Changjiang causes high turbidity in inshore area, which does not favor the growth of benthic microalgae on muddy to sandy sea floors. Our measurements of photosynthetically active radiation (PAR, data not shown), which is one of the critical factors for algal growth, demonstrated only $10-15 \mathrm{~m}$ of euphotic zone (the depth with $0.6 \%$ of surface light irradiation, Chen et al., 1999) in the inner shelf. However, our inshore sampling sites were generally deeper than $30 \mathrm{~m}$. Nadon and Himmelman (2006) also observed enriched ${ }^{13} \mathrm{C}$ signatures of benthos in waters far removed from sources of benthic microalgae implying that some factors other than the uptake of benthic primary production affect the carbon ratios in benthic consumers, such as phytoplankton blooms and consumers' selective feeding on ${ }^{13} \mathrm{C}$-enriched organic matter. Therefore, the benthic consumers in our inshore survey area may receive little nourishment from benthic primary producers such as micro- and macroalgae.

\subsection{Variation in carbon isotope values of benthic consumers}

Even though the in situ marine production constituted a major proportion of the food source for benthic communities across the shelf, large variation in $\delta^{13} \mathrm{C}$ values still occurred in fish and crustaceans across the shelf, with $0.9-3.2 \%$ o higher at the inshore sites ( $<150 \mathrm{~km}$ from the shore) than offshore sites. This isotopic trend involving ${ }^{13} \mathrm{C}$-enrichment for nearshore shelf relative to offshore slope was widely observed, with the spatial difference in $\delta^{13} \mathrm{C}$ values $=0.6-3.3 \%$ for zooplankton (Perry et al., 1999; Miller et al., 2008) and about $2.2 \%$ for benthic crustacean stomach content along the shelf-slope transect (Fry, 2011). However, whether this isotopic trend is associated with adjacent river discharge or just reflects a normal depth-related productivity gradient was still doubtful (Fry, 2011). The current study displayed different extents of the cross-shelf enrichment in fish $\delta^{13} \mathrm{C}$ values between high and low river discharge conditions. During the Changjiang river flood period (July 2010), the most obvious cross-shelf trend in fish $\delta^{13} \mathrm{C}$ values was observed. At that time, phytoplankton fixation of carbon was nearly 3-times-higher than in non-flood seasons (Gong et al., 2011) and the phytoplankton assemblages were largely dominant by ${ }^{13} \mathrm{C}$-rich diatom blooms $\left(\delta^{13} \mathrm{C}=-20 \%\right.$ o to $-15 \%$; Fry and Wainright, 1911). Contrarily, the smallest cross-shelf enrichment in fish $\delta^{13} \mathrm{C}$ values was observed in July 2009 when the Changjiang discharge was low and none of our sampling sites for demersal fish situated in the Changjiang diluted water affected area (CDW; salinity $<31$, Gong et al., 2011). Evidently, the current study provided preliminary evidence that the carbon isotopic trend of fish across the ECS continental shelf was closely related to the Changjiang discharge.

Both higher trophic levels of fish and more enriched baseline isotopic signatures of food web in the inner shelf could form the declining trend of fish $\delta^{13} \mathrm{C}$ values in addition to uptake of different food sources (Vander Zanden and Vadeboncoeur, 2002; Gerdeaux and Perga, 2006). The trophic levels of fish assemblages estimated by $\delta^{15} \mathrm{~N}$ values showed little change among sampling sites. Fish species A. hexanema even had slightly lower trophic levels at inshore sites (Supplementary Table 1), thus implying that the conventional trophic enrichment were not the main factor affecting the isotopic variability of the demersal fish. Instead, it was attributed to the variability in 'baseline' carbon isotopic ratios of food webs across the ECS continental shelf. This variability can be supported by the higher $\delta^{13} \mathrm{C}$ values for inshore phytoplankton and zooplankton.

The $\delta^{13} \mathrm{C}$ values of primary producers are well dependent on the carbon isotope fractionation during photosynthesis (Raven et al., 1994), which is mainly relevant to growth rate, carbon transport pathway, and geometry of phytoplankton cells (Fry and Wainright, 1911; Fry, 1996; Popp et al., 1998). Plenty of field studies observed higher $\delta^{13} \mathrm{C}$ values of primary producers (generally $\geqq 3 \%$ ) during development of phytoplankton blooms (Fry and Wainright, 1911; Savoye et al., 2003; Tamelander et al., 2009), and found strong positive correlations between POM $\delta^{13} \mathrm{C}$ values and rates of phytoplankton primary production (Cifuentes et al., 1988) as well as in situ POC concentration (Savoye et al., 2003). This is due to the fact that under the condition of high photosynthetic rates, ambient DIC would be largely consumed by massive algae blooms and most DIC entering the algal cells would soon be used for carboxylation, thus involving very little isotopic fractionation (Fry, 1996; Popp et al., 1998). On the other hand, as the phytoplankton grow rapidly, it may adopt active transport of $\mathrm{HCO}_{3}{ }^{-}$whereby the carbon isotope fractionation would be quite small (Fogel and Cifuentes, 1993). Tortell et al. (2000) further demonstrated nearly unchanged low carbon isotope fractionation (ca 5\%) and high growth rate across a wide range of DIC concentrations in seawater. In the current study, those sampling sites characterized by high $\delta^{13} \mathrm{C}$ values for fish muscle (i.e., O1, A1, $\mathrm{B} 1$, and $\mathrm{C} 1$ ) exactly corresponded to the Changjiang plume area where algal blooms occurred frequently in May and June (Tang et al., 2006; Wang and Wu, 2009). Though the exact physiological mechanism of inorganic carbon transport (active or diffusive) cannot be inferred from the isotopic ratios of phytoplankton per se, the observed high $\delta^{13} \mathrm{C}$ values for inshore organisms were very likely reflecting the depressed photosynthetic fractionation caused by rapid growth of algae.

Additionally, in the period of high primary productivity, the predominant components of ambient DIC pool tends to shift from heterotrophic $\mathrm{CO}_{2}$ to atmospheric $\mathrm{CO}_{2}$ (Woodland et al., 2012), which are more ${ }^{13} \mathrm{C}$-enriched $\left(\delta^{13} \mathrm{C}=-8 \%\right.$ o to $-7 \%$ o ) relative to riverine (Fry and Allen, 2003) and remineralized carbon ( $-20 \%$ o to $-35 \%$; Schindler et al., 1997). This seasonal sink of atmospheric $\mathrm{CO}_{2}$ was also frequently observed in the Changjiang freshwater influenced inner shelf (Chou et al., 2009). Tamelander et al. (2009) further found a significantly positive correlation between the $\delta^{13} \mathrm{C}$ values for DIC $\left(\delta^{13} C_{\text {DIC }}\right)$ and biological uptake of inorganic carbon $\left(\mathrm{CO}_{2}\right.$ from the atmosphere included $)$ as the algae blooms, thus 
ascribing the seasonal variation in $\mathrm{POC} \delta^{13} \mathrm{C}$ values to the influence of atmospheric $\mathrm{CO}_{2}$ intrusion.

As a whole, the biogeochemical properties in the ECS proved that the higher $\delta^{13} \mathrm{C}$ values for inshore phytoplankton against the backdrop of ${ }^{13} \mathrm{C}$-depleted offshore phytoplankton was resulted from the sequential and collective effects of decreased photosynthetic fractionation arising from fast algal growth and depleted ambient DIC coupled with utilization of ${ }^{13} \mathrm{C}$-enriched atmospheric $\mathrm{CO}_{2}$, as demonstrated in various aquatic ecosystems (e.g. Schindler et al., 1997; Gerdeaux and Perga, 2006; Tamelander et al., 2009; Woodland et al., 2012). The significant positive correlation between concentrations of chlorophyll $a$ and nutrients versus fish $\delta^{13} \mathrm{C}$ (Fig. 7) further revealed the propagation of this isotopic variability as a bottom-up label across the trophic levels to benthic consumers. Collectively, the cross-shelf trend in carbon isotope ratios was correlated to the Changjiang discharge, with a larger extent of inshore ${ }^{13} \mathrm{C}$-enrichment during the large flow period.

\subsection{Variation in nitrogen isotope values of benthic consumers}

In terms of nitrogen isotopes, inshore zooplankton and crustaceans exhibited consistently higher variability in $\delta^{15} \mathrm{~N}$ values than on the outer shelf. Our observation was supported by the result of a meta-analysis conducted by Woodland et al. (2012) that demonstrated more pronounced standard deviation of $\delta^{15} \mathrm{~N}$ values $\left(\mathrm{SD}_{\delta \mathrm{N}}\right)$ for the invertebrates inhabiting eutrophic ecosystems than in oligotrophic habitats. In the inner shelf, multiple nitrogen sources was conveyed from the Changjiang freshwater, including ${ }^{15} \mathrm{~N}$-depleted agricultural fertilizer and atmospheric deposition and ${ }^{15} \mathrm{~N}$-enriched urban sewage effluent, and animal waste (Li et al., 2010). Although the nitrate $\left(\mathrm{NO}_{3}{ }^{-}\right)$from riverine inputs tended to reveal a collective signal for the nitrogen isotope, Liu et al. (2009) revealed largest variation in $\delta^{15} \mathrm{~N}$ values in the adjacent ECS relative to the upper Changjiang Estuary and the turbid maximum zone. It is because the intense biological assimilation in the inner shelf can greatly promote nitrogen isotopic fractionation and further cause a progressive enrichment of ${ }^{15} \mathrm{~N}$ in the residual nitrate due to the phytoplankton preference for ${ }^{14} \mathrm{NO}_{3}$ rather than ${ }^{15} \mathrm{NO}_{3}$ (Fogel and Cifuentes, 1993; Savoye et al., 2003; Liu et al., 2009; Tamelander et al., 2009). In addition, variability in the forms of $\mathrm{N}$ incorporated by algae also leads to large variation in the $\delta^{15} \mathrm{~N}$ values of primary production due to differential fractionation against ${ }^{15} \mathrm{~N}$ (Fogel and Cifuentes, 1993, Waser et al., 1998). Li et al. (2010) found that $\mathrm{NO}_{3}{ }^{-}$assimilation was the major pathway supporting the bloom (isotopic fractionation $=-4 \%$ o to $-5 \%$; Fogel and Cifuentes, 1993) as the ECS phytoplankton community was dominated by dinoglagellates. However, $\mathrm{NH}_{4}^{+}$assimilation became prevalent (isotopic fractionation $=-10 \%$; Fogel and Cifuentes, 1993) when dominant species was succeeded by Prorocentrum donghaiense, which was also the most common bloomforming algae off the ECS coast. Accordingly, zooplankton and other invertebrate with smaller biomass would mirror the contemporaneous fluctuations in the isotopic compositions of phytoplankton (Woodland et al., 2012). In addition, the nitrogen isotope ratios are very sensitive to changes in the food web structure. The significantly negative correlations between fish $\delta^{15} \mathrm{~N}$ values and concentrations of nutrients were likely to indicate the simplified community structures and slightly lower trophic levels of fish arising from the eutrophication and hypoxia in the ECS inshore ecosystem (Chang et al., 2012).

In contrast, the sources of DIN in the outer shelf are not as diverse as those in the inner shelf. Besides, no algal bloom event was observed in the outer shelf because the ambient concentration of $\mathrm{NO}_{3}{ }^{-}$was 1-2 orders of magnitude smaller than in the inner shelf. Due to the scarcity of $\mathrm{N}$ availability, the nitrogen isotopic fractionation during photosynthetic assimilation was generally lower and the variation in phytoplankton $\delta^{15} \mathrm{~N}$ values was smaller than in eutrophic regions (Fogel and Cifuentes, 1993).

\subsection{Biomass-dependent variability in isotopic compositions}

In this study, zooplankton, crustaceans, and fish showed different levels of isotopic enrichment across the ECS continental shelf. The larger spatial variations in $\delta^{13} \mathrm{C}$ values for fish and crustaceans can be attributed to their longer organism longevity and lower isotopic turnover rates (Perga and Gerdeaux, 2005). The fish muscle collected in the summer may mainly reflect the integrated $\delta^{13} \mathrm{C}$ and $\delta^{15} \mathrm{~N}$ composition of food sources from spring to summer, which corresponds to their somatic growth period (i.e., protein synthesis, Perga and Gerdeaux, 2005). The greater longevity of benthic fish and crustaceans allowed them to accumulate the elevated $\delta^{13} \mathrm{C}$ values induced by algal blooms in the inner shelf year after year. Therefore, the large spatial variations in $\delta^{13} \mathrm{C}$ values for benthic crustaceans and fish in the summer surveys probably reflected the repeated ingestion of $\mathrm{C}$ source from fast growing algae (May-June in the ECS, Tang et al., 2006) by the inshore consumers and the assimilation of general phytoplankton by the offshore consumers.

\section{Conclusion}

The Changjiang riverborne nutrients play an important role in linking the trophic structure of marine benthic ecosystems to pelagic primary productivity as well as to the terrestrial watershed by stimulating algal blooms that become major food sources. In contrast, the riverborne POM exhibited a relatively limited contribution to the sustenance of the inshore benthic communities. The less utilization of terrestrial organic matter by marine benthic consumers may reflect both its fewer abundance in the environment and the nature of low $\mathrm{N}$ content. The ${ }^{13} \mathrm{C}$-enriched isotopic signatures of primary producers and of subsequent consumers reflected a lower photosynthetic fractionation during the algal blooms, an effect that was further enhanced during flood river flows into the ECS. Moreover, organisms belonging to different trophic levels showed various magnitudes yet consistent trend of carbon isotope enrichment, proving the bottom-up labeling of distinct isotopic signal on the whole food web. The current study provided a clear insight into the variability in isotopic ratios across an extensively river-influenced continental shelf system.

\section{Acknowledgements}

This investigation was funded by the National Science Council (NSC), Taiwan under Grant no. NSC 102-2611-M-002-009. We are grateful for the constructive comments on the manuscript by Brian Jessop. We also thank Wei-Hsuan Teng, Pei-Chi Ho, Wei-Ju Chien and the crew of the Ocean Researcher I for laboratory and field assistances.

\section{Appendix A. Supporting information}

Supplementary data associated with this article can be found in the online version at: http://dx.doi.org/10.1016/j.csr.2014.04.021.

\section{References}

Antonio, E.S., Kasai, A., Ueno, M., Won, N., Ishihi, Y., Yokoyama, H., Yamashita, Y., 2010. Spatial variation in organic matter utilization by benthic communities from Yura River-Estuary to offshore of Tango Sea, Japan. Estaur. Coast. Shelf Sci. 86, 107-117. 
Antonio, E.S., Kasai, A., Ueno, M., Ishihi, Y., Yokoyama, H., Yamashita, Y., 2012 Spatial-temporal feeding dynamics of benthic communities in an estuarymarine gradient. Estuar. Coast. Shelf Sci. 112, 86-97.

Bouillon, S, Chandra Mohan, P., Sreenivas, N., Dehairs, F., 2000. Sources of suspended organic matter and selective feeding by zooplankton in an estuarine mangrove ecosystem as traced by stable isotopes. Mar. Ecol. Prog. Ser. 208, 79-92.

Breitburg, D., 2002. Effects of hypoxia, and the balance between hypoxia and enrichment, on coastal fishes and fisheries. Estuaries 25, 767-781.

Chang, N.N., Shiao, J.C., Gong, G.C., 2012. Diversity of demersal fish in the East China Sea: Implication of eutrophication and fishery. Cont. Shelf Res. 47, 42-54.

Chen, C.C., Gong, G.C., Shiah, F.K., 2007. Hypoxia in the East China Sea: One of the largest coastal low-oxygen areas in the world. Mar. Environ. Res. 64, 399-408.

Chen, Y.L.L., Lu, H., Shiah, F. Gong, G. Liu, K., Kanda, J., 1999. New production and fratio on the continental shelf of the East China Sea: comparisons between nitrate inputs from the subsurface Kuroshio Current and the Changjiang River. Estuar. Coast. Shelf Sci. 48, 59-75.

Chou, W.C., Gong, G.C., Sheu, D.D., Jan, S., Hung, C.C., Chen, C.C., 2009. Reconciling the paradox that the heterotrophic waters of the East China Sea shelf act as significant $\mathrm{CO}_{2}$ sink during the summertime: evidence and implications. Geophys. Res. Lett. 36, L15607.

Cifuentes, L.A., Sharp, J.H., Fogel, M.L., 1988. Stable carbon and nitrogen isotope biogeochemistry in the Delaware estuary. Limnol. Oceanogr. 33, 1102-1115.

Cividanes, S., Incera, M., Lopez, J., 2002. Temporal variability in the biochemica composition of sedimentary organic matter in an intertidal flat of the Galician coast (NW Spain). Oceanol. Acta 25, 1-12.

Dagg, M., Benner, R., Lohrenz, S., Lawrence, D., 2004. Transformation of dissolved and particulate materials on continental shelves influenced by large rivers: plume processes. Cont. Shelf Res. 24, 833-858.

Darnaude, A.M., Salen-Picard, C., Polunin, N.V.C., Harmelin-Vivien, M.L., 2004 Trophodynamic linkage between river runoff and coastal fishery yield elucidated by stable isotope data in the Gulf of Lions (NW Mediterranean). Oecologia $138,325-332$.

Deegan, L.A., Garritt, R.H., 1997. Evidence for spatial variability in estuarine food webs. Mar. Ecol. Prog. Ser. 147, 31-47.

Diaz, F., Raimbault, P., Boudjellal, B., Garcia, N., Moutin, T., 2001. Early spring phosphorus limitation of primary productivity in a NW Mediterranean coasta zone (Gulf of Lions). Mar. Ecol. Prog. Ser. 211, 51-62.

Diaz, R., Selman, M., Chique, C., 2011. World Resources Institute.

Diaz, R.J., 2001. Overview of hypoxia around the World. J. Environ. Qual. 30, 275-281.

Evrard, V., Soetaert, K., Heip, C.H.R., Huettel, M., Xenopoulos, M.A., Middelburg, J.J. 2010. Carbon and nitrogen flows through the benthic food web of a photic subtidal sandy sediment. Mar. Ecol. Prog. Ser. 416, 1-16.

Fogel, M.L., Cifuentes, L.A., 1993. Isotope fractionation during primary production. In: Engel, M.H., Macko, S.A. (Eds.), Organic Geochemistry. Plenum Press, New York, pp. 73-98.

Fry, B., 1996. ${ }^{13} \mathrm{C} /{ }^{12} \mathrm{C}$ fractionation by marine diatoms. Mar. Ecol. Prog. Ser. 134, 283-294.

Fry, B., 2011. Mississippi River sustenance of brown shrimp (Farfantepenaeus aztecus) in Louisiana coastal waters. Fish. Bull. 109, 147-161.

Fry, B., Allen, Y.C., 2003. Stable isotopes in zebra mussels as bioindicators of riverwatershed linkages. River Res. Appl. 7, 683-696.

Fry, B., Wainright, S.C., 1911. Diatom sources of ${ }^{13} \mathrm{C}$-rich carbon in marine food webs. Mar. Ecol. Prog. Ser. 76, 149-157.

Galloway, J.N., Dentener, F.J., Capone, D.G., Boyer, E.W., Howarth, R.W., Seitzinger, S P., Asner, G.P., Cleveland, C.C., Green, P.A., Holland, E.A., Karl, D.M., Michaels, A F., Porter, J.H., Townsend, A.R., Voosmarty, C.J., 2004. Nitrogen cycles: past, present, and future. Biogeochemistry 70, 153-226.

Gao, S., Wang, Y.P., 2008. Changes in material fluxes from the Changjiang River and their implications on the adjoining continental shelf ecosystem. Cont. Shelf Res. 28, 1490-1500.

Gearing, P.J., Gearing, J.N., Maughan, J.T., Oviatt, C.A., 1991. Isotopic distribution of carbon from sewage sludge and eutrophication in the sediments and food web of estuarine ecosystems. Environ. Sci. Technol. 25, 295-301.

Gerdeaux, D., Perga, M.E., 2006. Changes in whitefish scales $\delta^{13} \mathrm{C}$ during eutrophication and reoligophication of subalpine lakes. Limnol. Oceanogr. 51, 772-780.

Gong, G.C., Liu, K.K., Chiang, K.P., Hsiung, T.M., Chang, J., Chen, C.C., Hung, C.C., Chou, W.C., Chung, C.C., Chen, H.Y., Shiah, F.K., Tsai, A.Y., Hsieh, C.H., Shiao, J.C., Tseng, C.M., Hsu, S.C., Lee, H.J., Lee, M.A., Lin, I.I., Tsai, F., 2011. Yangtze River floods enhance coastal ocean phytoplankton biomass and potential fish production. Geophys. Res. Lett. 38, L13603.

Gong, G.C., Shiah, F.K., Liu, K.K., Wen, Y.H., Liang, M.H., 2000. Spatial and temporal variation of chlorophyll a, primary productivity and chemical hydrography in the southern East China Sea. Cont. Shelf Res. 20, 411-436.

Gong, G.C., Wen, W.H., Wang, B.W., Liu, G.J., 2003. Seasonal variation of chlorophyll a concentration, primary production and environmental conditions in the subtropical East China Sea. Deep Sea Res. Part II 50, 1219-1236.

Graf, G., 1992. Benthic-pelagic coupling - a benthic view. Oceanogr. Mar. Biol. 30, 149-190.

Grall, J., Chauvaud, L., 2002. Marine eutrophication and benthos: the need for new approaches and concepts. Glob. Change Biol. 8, 813-830.

Hedges, J.I., Keil, R.G., Benner, R., 1997. What happens to terrestrial organic matter in the ocean? Org. Geochem. 27, 195-212.

Howarth, R.W., Jensen, H., Marino, R., Postma, H., 1995. Transport to and processing of phosphorus in near-shore and oceanic waters. In: Tiessen, H. (Ed.), Phosphorus in the Global Environment: Transfers, Cycles, and Management. John Wiley and Sons, Chichester, UK.
Hunter, W.R., Jamieson, A., Huvenne, V.A.I., Witte, U., 2013. Sediment community responses to marine vs. terrigenous organic matter in a submarine canyon. Biogeosciences 10, 67-80.

Kanaya, G., Takagi, S., Nobata, E., Kikuchi, E., 2007. Spatial dietary shift of macrozoobenthos in a brackish lagoon revealed by carbon and nitrogen stable isotope ratios. Mar. Ecol. Prog. Ser. 345, 117-127.

Kao, S.J., Lin, F.J., Liu, K.K., 2003. Organic carbon and nitrogen contents and their isotopic compositions in surficial sediments from the East China Sea shelf and the southern Okinawa Trough. Deep-Sea Res. Part II 50, 1203-1217.

Leakey, C.D.B., Attrill, M.J., Jennings, S., Fitzsimons, M.F., 2008. Stable isotopes in juvenile marine fishes and their invertebrate prey from the Thames Estuary, UK, and adjacent coastal regions. Estuar. Coast. Shelf Sci. 77, 513-522.

Li, J., Glibert, P.M., Zhou, M., 2010. Temporal and spatial variability in nitrogen uptake kinetics during harmful dinoflagellate blooms in the East China Sea. Harmful Algae 9, 531-539.

Li, S.L., Liu, C.O., Li, J., Liu, X., Chetelat, B., Wang, B., Wang, F., 2010. Assessment of the sources of nitrate in the Changjiang River, China: using a nitrogen and oxygen isotopic approach. Environ. Sci. Technol., 44; , pp. 1573-1578.

Liu, X., Yu, Z., Song, X., Cao, X., 2009. The nitrogen isotopic composition of dissolved nitrate in the Yangtze River (Changjiang) estuary, China. Estuar. Coast. Shelf Sci. 85, 641-650.

Mann, K.H., 1988. Production and use of detritus in various freshwater, estuarine, and coastal marine ecosystems. Limnol. Oceanogr. 33, 910-930.

Miller, T.W., Brodeur, R.D., Rau, G.H., 2008. Carbon stable isotopes reveal relative contribution of shelf-slope production to the northern California Current pelagic community. Limnol. Oceanogr. 53, 1493-1503.

Minagawa, M., Wada, E., 1984. Stepwise enrichment of $\delta^{15} \mathrm{~N}$ along food chains: further evidence and the relation between $\delta^{15} \mathrm{~N}$ and animal age. Geochim. Cosmochim. Acta 48, 1135-1140.

Nadon, M.O., Himmelman, J.H., 2006. Stable isotopes in subtidal food webs: have enriched carbon ratios in benthic consumers been misinterpreted? Limnol. Oceanogr. 51, 2828-2836.

Nascimento, F.J.A., Karlson, A.M.L., Elmgren, R., 2008. Settling blooms of filamentous cyanobacteria as food for meifauna assemblages. Limnol. Oceanogr. 53, 2636-2643.

Nixon, S.W., 1995. Coastal marine eutrophication: a definition, social causes, and future concerns. Ophelia 41, 199-219.

Nixon, S.W., Oviatt, C.A., Frithsen, J., Sullivan, B., 1986. Nutrients and the productivity of estuarine and coastal marine ecosystems. J. Limnol. Soc. S. Afr. 12, 43-71.

Pai, S.C., Yang, C.C., Riley, J.P., 1990. Effects of acidity and molybdate concentration on the kinetics of the formation of the phosphoantimonyl molybdenum blue complex. Anal. Chim. Acta 229, 115-120.

Parnell, A., Inger, R., Bearhop, S., Jackson, A.L., 2008. SIAR: stable isotope analysis in R. 〈http://cran.r-project.org/web/packages/siar/index.html .

Parsons, T.R., Maita, Y., Lalli, C.M., 1984. A Manual of Chemical and Biological Methods for Seawater Analysis. Pergamon Press, New York, pp. 1-184.

Perga, G., Gerdeaux, D., 2005. 'Are fish what they eat' all year round? Oecologia 144, $598-606$.

Perry, R.I., Thompson, P.A., Mackas, D.L., Harrison, P.J., Yelland, D.R., 1999. Stable carbon isotopes as pelagic food web tracers in adjacent shelf and slope regions off British Columbia, Canada. Can. J. Fish. Aquat. Sci. 56, 2477-2486.

Peters, K.E., Sweeney, R.E., Kaplan, I.R., 1978. Correlation of carbon and nitrogen stable isotope ratios in sedimentary organic matter. Limnol. Oceanogr. 23, 598-604.

Peterson, B.J., Howarth, R.W., Garritt, R.H., 1985. Multiple stable isotopes used to trace the flow of organic matter in estuarine food webs. Science 227, 1361-1363.

Popp, B.N., Laws, E.A., Bidigare, R.R., Dore, J.E., Hanson, K.L., Wakeham, S.G., 1998. Effect of phytoplankton cell geometry on carbon isotopic fractionation. Geochim. Cosmochim. Acta 62, 69-77.

Post, D.M., 2002. Using stable isotopes to estimate trophic position: models, methods, and assumptions. Ecology 83, 703-718.

Raven, J.A., Johnston, A.M., Newman, J.R., Scrim-Geour, C.M., 1994. Inorganic carbon acquisition by aquatic photo-lithotrophs of the Dighty Bum, Angus, U.K.: uses and limitations of natural abundance measurements of carbon isotopes. New Phytol. 127, 271-286.

Riera, P., Richard, P., 1996. Isotopic determination of food sources of Crassostrea gigas along a trophic gradient in the estuarine bay of Marennes-Oléron. Estuar. Coast. Shelf Sci. 42, 347-360.

Savoye, N., Aminot, A., Tréguer, P., Fontugne, M., Naulet, N., Kérouel, R., 2003. Dynamics of particulate organic matter $\delta^{15} \mathrm{~N}$ and $\delta^{13} \mathrm{C}$ during spring phytoplankton blooms in a macrotidal ecosystem (Bay of Seine, France). Mar. Ecol. Prog. Ser. 255, 27-41.

Schindler, D.E., Carpenter, S.R., Cole, J.J., kitchell, J.E., Pace, M.L., 1997. Influence of food web structure on carbon exchange between lakes and the atmosphere. Science 277, 248-250.

Smith, V.H., 2003. Eutrophication of freshwater and coastal marine ecosystems: a global problem. Environ. Sci. Pollut. Res. 10, 1-14.

Sweeting, C.J., Polunin, N.V.C., Jennings, S., 2006. Effects of chemical lipid extraction and arithmetic lipid correction on stable isotope ratios of fish tissues. Rapid Commun. Mass Spectrom. 20, 595-601.

Tang, D.L., Di, B.P., Wei, G.F., Ni, I.H., Oh, I.S., Wang, S.F., 2006. Spatial, seasonal and species variations of harmful algal blooms in the South Yellow Sea and East China Sea. Hydrobiologia 568, 245-253.

Tamelander, T., Kivimae, C., Bellerby., R.G.J, Renaud, P.E., Kristiansen, S., 2009. Baseline variations in stable isotope values in an Arctic marine ecosystem: effects of carbon and nitrogen uptake by phytoplankton. Hydrobiologia 630, 63-73. 
Tortell, P.D., Rau, G.H., Morel, F.M.M., 2000. Inorganic carbon acquisition in coastal Pacific phytoplankton communities. Limnol. Oceanogr. 45, 1485-1500.

Vadeboncoeur, Y., Jeppeson, E., Vanderz, A.M.J., Schierup, H., Chistoffersen, K., lodge, D.M., 2003. Cultural eutrophication and the loss of benthic energy pathways in lakes. Limnol. Oceanogr. 48, 1408-1418.

Vander Zanden, M.J., Vadeboncoeur, Y., 2002. Fishes as integrators of benthic and pelagic food webs in lakes. Ecology 83, 2152-2161.

Voss, M., Struck, U., 1997. Stable nitrogen and carbon isotopes as indicator of eutrophication of the Oder river (Baltic sea). Mar. Chem. 59, 35-49.

Wada, E., Mizutami, H., Minagawa, M., 1991. The use of stable isotopes for food web analysis. Crit. Rev. Food Sci. Nutr. 30, 361-371.

Wada, E.M., Minagawa, H., Mizutani, H., Tsuji, T., Imaizumi, R., Karasawa, K., 1987. Biogeochemical studies on the transport of organic matter along the Otsuchi River watershed, Japan. Estuar. Coast. Shelf Sci. 25, 321-336.

Wang, B., 2006. Cultural eutrophication in the Changjiang (Yangtze River) plume: history and perspective. Estuar. Coast. Shelf Sci. 69, 471-477.

Wang, J., Wu, J., 2009. Occurrence and potential risks of harmful algal blooms in the East China Sea. Sci. Total Environ. 407, 4012-4021.

Waser, N.A., Yin, K.D., Yu, Z.M., Tada, K., Harrison, P.J., Turpin, D.H., Calvert, S.E., 1998. Nitrogen isotope fractionation during nitrate, ammonium and urea uptake by marine diatoms and coccolithophores under various conditions of N availability. Mar. Ecol. Prog. Ser. 169, 29-341.

Welschmeyer, N.A., 1994. Fluorometric analysis of chlorophyll a in the presence of chlorophyll $b$ and pheopigments. Limnol. Oceanogr. 39, 1985-1992.

Woodland, R.J., Magnan, P., Glemet, H., Rodriguez, M.A., Cabana, G., 2012. Variability and directionality of temporal change in $\delta^{13} \mathrm{C}$ and $\delta^{15} \mathrm{~N}$ of aquatic invertebrate primary consumers. Oecologia 169, 199-209.

Wu, Y., Dittmar, T., Ludwichowski, K.U., Kattner, G., Zhang, J., Zhu, Z.Y., Koch, B.P., 2007a. Tracing suspended organic nitrogen from the Yangtze River catchment into the East China Sea. Mar. Chem. 107, 367-377.

Wu, Y., Zhang, J., Li, D.J., Wei, H., Lu, R.H., 2003. Isotope variability of particulate organic matter at the PN section in the East China Sea. Biogeochemistry 65 31-49.

Wu, Y., Zhang, J., Liu, S.M., Zhang, Z.F., Yao, Q.Z., Hong, G.H., Copper, L., 2007b. Sources and distribution of carbon within the Yangtze River system. Estuar Coast. Shelf Sci. 71, 13-25.

Zhou, M.J., Shen, Z.L., Yu, R.C., 2008. Responses of a coastal phytoplankton community to increased nutrient input from the Changjiang (Yangtze) River. Cont. Shelf Res. 28, 1483-1489. 